Article

\title{
Cyclometalated Iridium(III) Complexes Containing Benzoxazole Derivatives and Different Ancillary Ligands for Catalytic Oxidation of Toluene
}

\author{
Kelvin H.-C. Chen ${ }^{1}$, Pei-Chun Liu ${ }^{1}$, Tsun-Ren Chen ${ }^{1, *}$ and Jhy-Der Chen ${ }^{2}$ \\ 1 Department of Applied Chemistry, National Pingtung University, Pingtung 90003, Taiwan; \\ kelvin@mail.nptu.edu.tw (K.H.-C.C.); Lpc1012@hotmail.com (P.-C.L.) \\ 2 Department of Chemistry, Chung-Yuan Christian University, Chung-Li 32023, Taiwan; jdchen@cycu.edu.tw \\ * Correspondence: trchen@mail.nptu.edu.tw; Tel.: +886-9-3326-1376
}

Received: 27 September 2018; Accepted: 26 October 2018; Published: 29 October 2018

\begin{abstract}
A series of cyclometalated iridium(III) complexes that have the general formula $\left[\left(\mathrm{C}^{\wedge} \mathrm{N}\right)_{2} \operatorname{Ir}(\mathrm{NR})(\mathrm{X})\right]\left(\mathrm{C}^{\wedge} \mathrm{N}=\right.$ monoanionic bidentate cyclometalating ligands; $\mathrm{NR}=$ pyridine derivatives; $\mathrm{X}=\mathrm{Cl}^{-}$or $\mathrm{I}^{-}$) are designed, prepared, and applied for the transformation of toluene to benzaldehyde using a clean, highly efficient, and environmentally-friendly process. The activation energies that are needed for the catalytic oxidation of toluene when using these complexes as catalysts are quite low: between 22.9 and $30.8 \mathrm{kcal} \mathrm{mol}^{-1}$. The catalytic frequencies (TOF) are fairly high (up to $7.0 \times 10^{2} \mathrm{~h}^{-1}$ ) with excellent reliability, and the turnover number (TON) can reach $4.2 \times 10^{3}$ after $6 \mathrm{~h}$ of processing time. Catalytic tests, $\mathrm{X}$-ray absorption near-edge structure (XANES), and kinetic modeling are used to derive detailed insights into the characteristics of the catalysts and their effects on the reactions that are featured in the catalytic oxidation of toluene.
\end{abstract}

Keywords: iridium; benzylic oxidation; benzaldehyde; green process

\section{Introduction}

The selective oxidation of toluene to benzaldehyde is an important issue in modern synthetic chemistry and pharmaceutical industry, as it provides the potential for the synthesis of fine chemicals and intermediates in an innovative fashion [1-4]. Previously, we have reported some cyclometalated iridium(III) complexes composed of benzoxazole ligand that can spontaneously release metalloradicals to promote two types of reactions: the carbon-hydrogen bond activation (CHA) and carbon-carbon bond activation (CCA) for ketones and aldehydes [5]. We have also demonstrated that the cyclometalated iridium(III) complexes could directly transform toluene into benzaldehyde [6].

Traditionally, benzaldehyde was produced through the oxidation of benzyl alcohol using stoichiometric amounts of halogenated reagents or chromium salts. This noncatalytic method showed a severe drawback in that the oxidant was environmentally unfriendly; therefore, tremendous efforts have been devoted to the design of catalytic systems that use $\mathrm{O}_{2}$ as the primary oxidant [7-20]. Although there have been some achievements for the catalytic oxidation of benzyl alcohols to prepare benzaldehydes [21-29], the preparation of benzyl alcohols is still a problem. Benzyl alcohols are commonly obtained through the halogenation of benzyl compounds; it is still a stoichiometric reaction with a highly harmful process.

In the previous report, several iridium complexes with a general formula $\left[\left(\mathrm{C}^{\wedge} \mathrm{N}\right)_{2} \operatorname{Ir}\left(\mathrm{N}^{\wedge} \mathrm{O}\right)\right]$ were prepared and used as catalysts for the direct transformation of toluene to benzaldehydes [30]. In the report, both $\mathrm{C}^{\wedge} \mathrm{N}$ and $\mathrm{N}^{\wedge} \mathrm{O}$ are monoanionic bidentate cyclometalating ligands. In solution, the $\mathrm{N}^{\wedge} \mathrm{O}$ ligand was firstly released from the complexes, and a four-coordinate intermediate with a vacant 
coordination site was formed. Experimental data showed that the catalytic capabilities of the complexes for the transformation of toluene were obviously affected by the structural character of the bidentate $\mathrm{C}^{\wedge} \mathrm{N}$ ligand. The catalytic rates by using previous complexes come to $3.44 \mu \mathrm{M} \mathrm{s}^{-1}$ with an excellent reliability under the processing conditions. To prepare more powerful catalysts for the transformation of benzyl compounds and investigate the factors that govern the catalytic ability, we have modified the structures of the complexes further. Herein, we report the design and synthesis of a series of cyclometalated iridium(III) complexes of the general formula $\left[\left(\mathrm{C}^{\wedge} \mathrm{N}\right) 2 \operatorname{Ir}(\mathrm{NR})(\mathrm{X})\right]\left(\mathrm{C}^{\wedge} \mathrm{N}=\right.$ monoanionic bidentate cyclometalating ligands; $\mathrm{NR}=$ pyridine derivatives; $\mathrm{X}=\mathrm{Cl}^{-}$or $\mathrm{I}^{-}$). Their application in the transformation of toluene to benzaldehyde forms the subject of this study. By applying these complexes to the transformation of toluene, the catalytic rates can reach $20.3 \mu \mathrm{M} \mathrm{s}^{-1}$ with fairly high turnover frequency (TOF up to $9940 \mathrm{~h}^{-1}$ ). Benzaldehyde is the major product in the reaction system; the selectivity of transforming toluene into benzaldehyde can be up to $97 \%$.

\section{Results and Discussion}

\subsection{Synthesis}

In this report, we designed and synthesized nine iridium complexes with the general formula $\left[\left(\mathrm{C}^{\wedge} \mathrm{N}\right)_{2} \operatorname{Ir}(\mathrm{NR})(\mathrm{X})\right]$. The notation $\mathrm{C}^{\wedge} \mathrm{N}$ represents monoanionic bidentate cyclometalating ligands, including 2-phenylbenzoxazolato (pbo) and 3,5-difluorophenyl benzoxazolato (dfpbo), whereas the NR ligands are pyridine derivatives, such as pyridine (py), 4-methylpyridine (4mpy), and 4-cyanopyridine (4cnpy), and $\mathrm{X}_{\text {is a } \mathrm{Cl}^{-}}$or $\mathrm{I}^{-}$anion. The molecular structures of the complexes are shown in Chart 1.
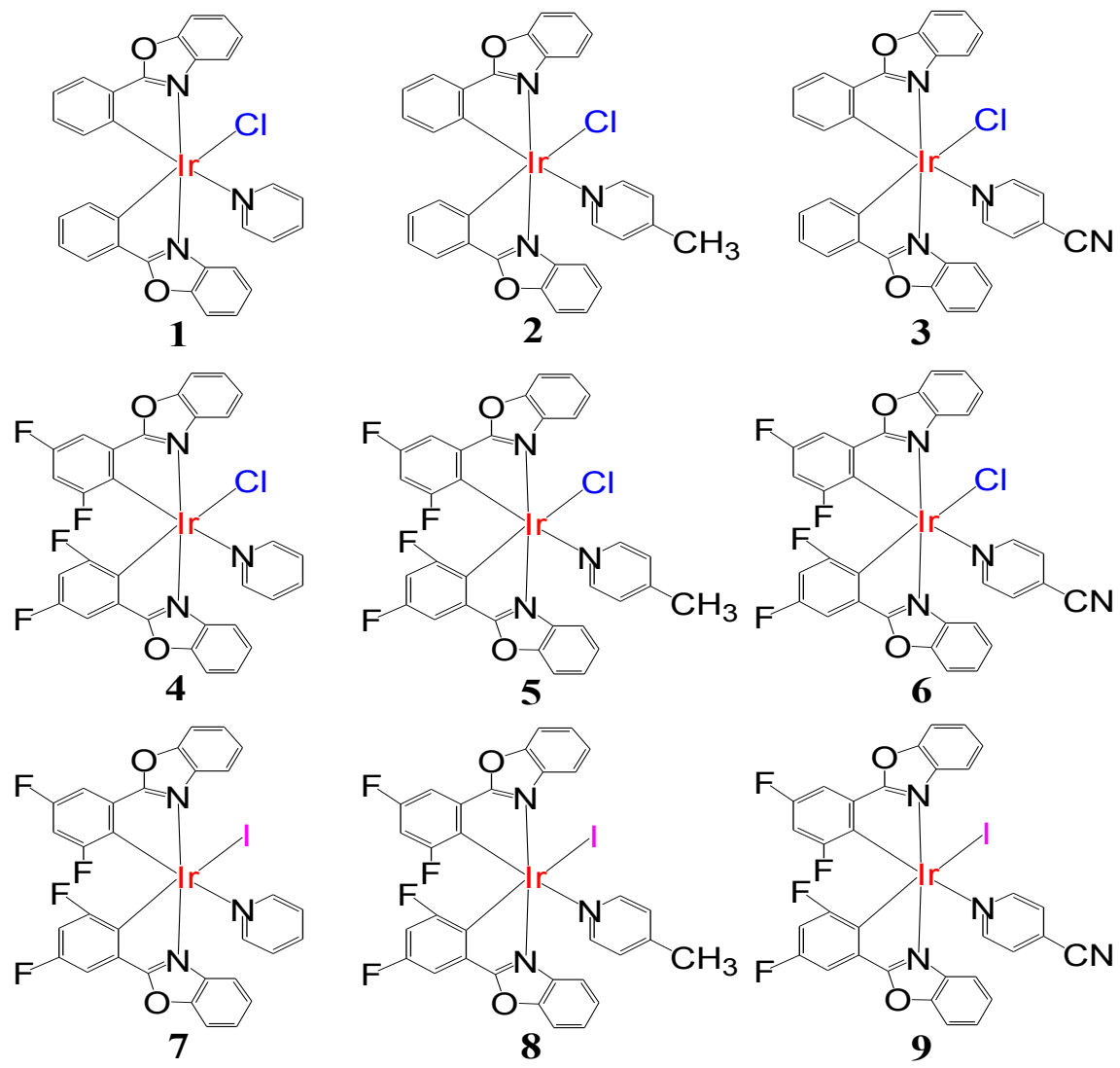

Chart 1. Molecular structure of complexes 1-9.

The synthetic route to the ligands and iridium complexes is illustrated in Scheme 1. Ligands, including 2-phenylbenzoxazole and 2-(3,5-difluorophenyl)benzoxazole (dfpbo), were prepared using Phillips condensation, as described in our previously reported procedure [31]. The cyclometalated 
$\operatorname{Ir}(\mathrm{III})$ chloro-bridged dimers, $\left[(\mathrm{pbo})_{2} \operatorname{Ir}(\mu-\mathrm{Cl})_{2} \operatorname{Ir}(\mathrm{pbo})_{2}\right](\mathrm{D} 1)$ and $\left[(\mathrm{dfpbo})_{2} \operatorname{Ir}(\mu-\mathrm{Cl})_{2} \operatorname{Ir}(\mathrm{dfpbo})_{2}\right](\mathrm{D} 2)$, were synthesized by a method also depicted in our previous reports [31,32]. Cyclometalated $\operatorname{Ir}(\mathrm{III})$ Iodo-bridged dimers, $\left[(\mathrm{dfpbo})_{2} \operatorname{Ir}(\mu-\mathrm{I})_{2} \operatorname{Ir}(\mathrm{dfpbo})_{2}\right]$ (D3), were synthesized according to the Finkelstein method. All of the iridium complexes were purified and identified by ${ }^{1} \mathrm{H}$ NMR, ${ }^{13} \mathrm{C}$ NMR, FAB-MS spectrometry, and elemental analyses. In addition, the complexes $(\mathrm{pbo})_{2} \operatorname{Ir}(\mathrm{Cl})(\mathrm{py})$ (1), (pbo $)_{2} \operatorname{Ir}(\mathrm{Cl})(4 \mathrm{mpy})(2),(\mathrm{dfpbo})_{2} \operatorname{Ir}(\mathrm{Cl})(\mathrm{py})(4),(\mathrm{dfpbo})_{2} \operatorname{Ir}(\mathrm{Cl})(4 \mathrm{mpy})(5),(\mathrm{dfpbo})_{2} \operatorname{Ir}(\mathrm{Cl})(4 \mathrm{cnpy})$ (6), (dfpbo $)_{2} \operatorname{Ir}(\mathrm{I})(4 \mathrm{mpy})$ (8), and $(\mathrm{dfpbo})_{2} \operatorname{Ir}(\mathrm{I})(4 \mathrm{cnpy})$ (9) were structurally characterized by X-ray crystallography.
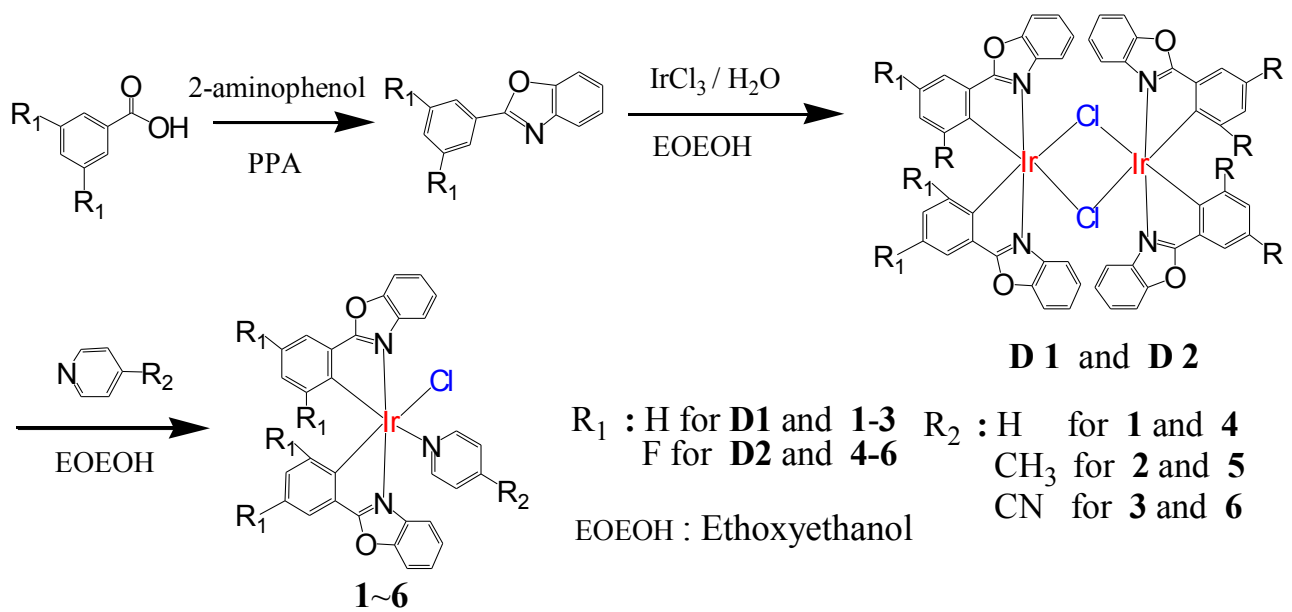

$\begin{array}{cc}\mathrm{R}_{1}: \mathrm{H} \text { for D1 and 1-3 } & \mathrm{R}_{2}: \mathrm{H} \text { for } \mathbf{1} \text { and } \mathbf{4} \\ \mathrm{F} \text { for D2 and 4-6 } & \mathrm{CH}_{3} \text { for } \mathbf{2} \text { and } \mathbf{5} \\ & \mathrm{CN} \text { for } \mathbf{3} \text { and } \mathbf{6}\end{array}$

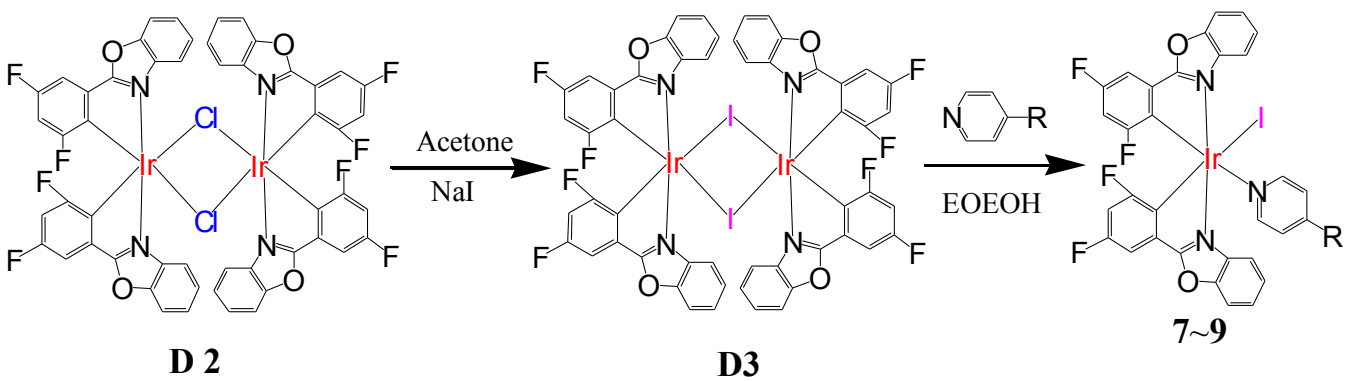

D 2

$\mathrm{R}: \mathrm{H}$ for $\mathbf{7}, \mathrm{CH}_{3}$ for $\mathbf{8} ; \mathrm{CN}$ for 9

Scheme 1. Synthetic route to ligands, iridium dimers D1-D3, and complexes 1-9.

In general, bidentate ligands can bind to the central metal tighter than monodentate ligands, and ionic ligands can bind to the central metal tighter than neutral ligands. Therefore, complexes 1-9 should easily release the neutral monodentate ligand to form an unsaturated structure $\left[\left(\mathrm{C}^{\wedge} \mathrm{N}\right)_{2} \operatorname{Ir}(\mathrm{Cl})\right]$ with a vacant site. The unsaturated structure is an electron acceptor (Lewis acid), which can accept some substrates possessing an electron pair or $\pi$-donor, and the coordinative unsaturation could facilitate carbon-hydrogen bond activation. The stability and reactivity of the complexes should depend on the characteristics of ligands $\mathrm{C}^{\wedge} \mathrm{N}$ and halogen.

\subsection{Crystal Structures}

The single-crystal structures of complexes 1, 2, 4-6, and 8-9 are represented with ORTEP diagrams in Figure 1. While the crystal of complex 1 conforms to the monoclinic space group $C 2 / c$, the crystals of complexes $\mathbf{2}, \mathbf{8}$ and $\mathbf{9}$ conform to the triclinic space group $P \overline{\mathbf{1}}$, and the crystal of complex $\mathbf{4}$ conforms to the monoclinic space group $P 2_{1} / n$, those of complexes 5 and $\mathbf{6}$ conform to the monoclinic space group $P 2_{1} / c$, respectively. Basic information pertaining to the crystal parameters and structure refinement is summarized in the Supporting Information. Selected bond distances and angles are listed in Table 1. The diversity of the space groups for this series of complexes suggested that the packing of these complexes was sensitive to the substituent of the ligands [32]. 


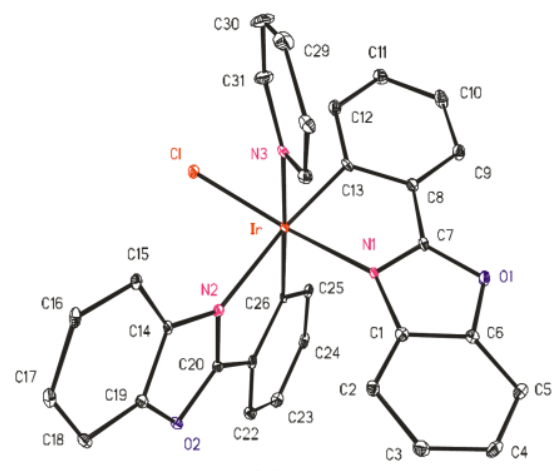

(a)

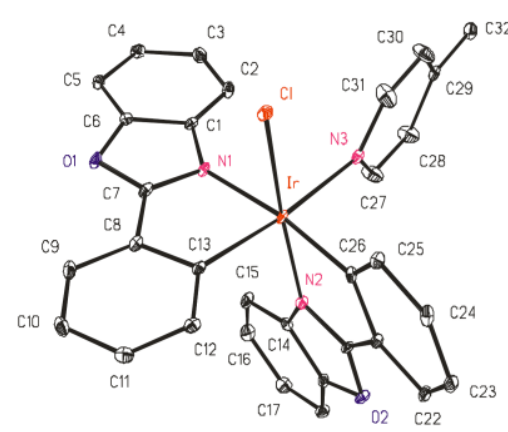

(b)

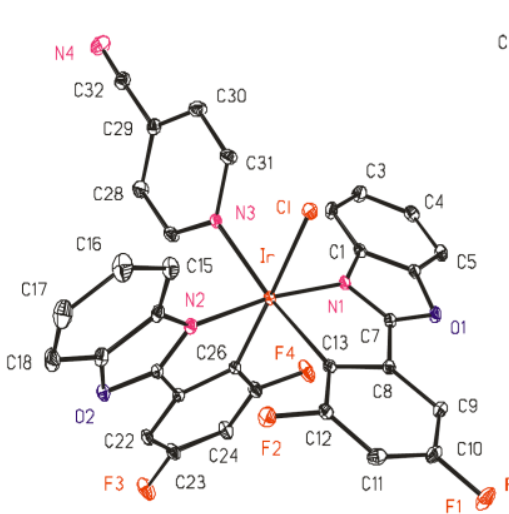

(e)

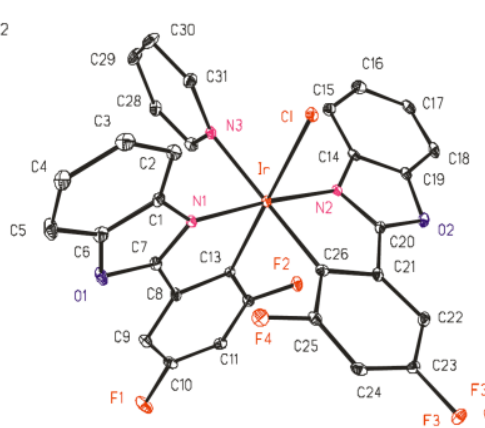

(c)

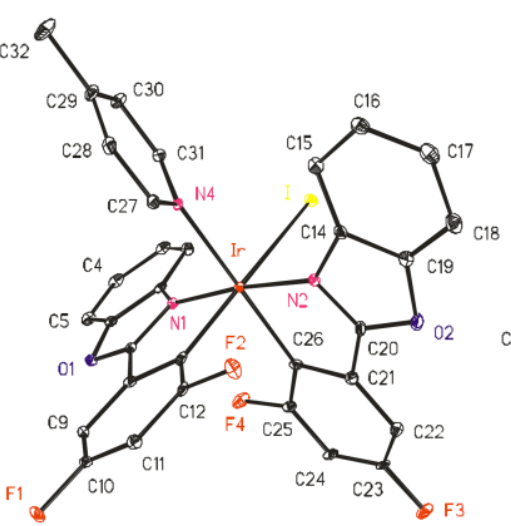

(f)

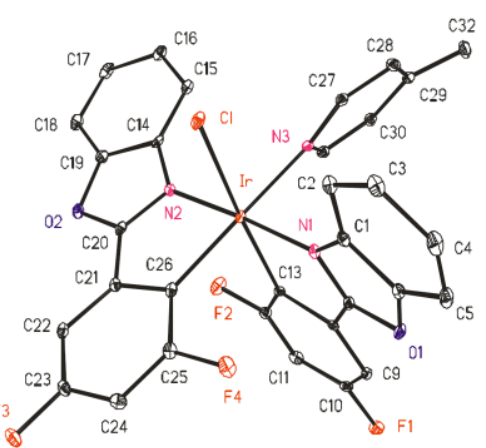

(d)

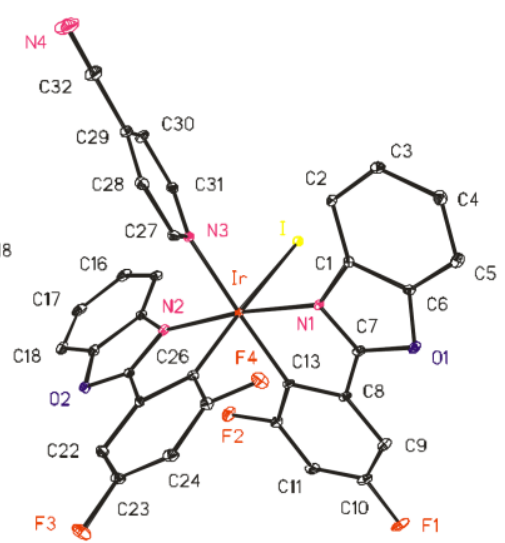

(g)

Figure 1. X-ray crystal structures of (a) (pbo $)_{2} \operatorname{Ir}(\mathrm{Cl})(\mathrm{py}) \quad(\mathbf{1}) ; \quad$ (b) (pbo $)_{2} \operatorname{Ir}(\mathrm{Cl})(4 \mathrm{mpy})$ (2); (c) (dfpbo) ${ }_{2} \operatorname{Ir}(\mathrm{Cl})(\mathrm{py})(\mathbf{4}) ;(\mathrm{d})(\mathrm{dfpbo})_{2} \operatorname{Ir}(\mathrm{Cl})(4 \mathrm{~m} \mathrm{py})(5) ;(\mathbf{e})(\mathrm{dfpbo})_{2} \operatorname{Ir}(\mathrm{Cl})(4 \mathrm{cnpy})(\mathbf{6}) ;(\mathrm{f})(\mathrm{dfpbo})_{2} \operatorname{Ir}(\mathrm{I})(4 \mathrm{~m}$ py) (8); and (g) (dfpbo) ${ }_{2} \operatorname{Ir}(\mathrm{I})(4 \mathrm{cnpy})(9)$. Thermal ellipsoids are draw at the $20 \%$ probability level. The hydrogen atoms and solvent are omitted for clarity. 
Table 1. Selected Bond Distance ( $\AA$ ) and Bond Angles for Complexes 1, 2, 4-6, and 8-9.

\begin{tabular}{|c|c|c|c|c|c|}
\hline \multicolumn{6}{|c|}{ Bond Distance (Å) } \\
\hline Complex & $\mathrm{Ir}-\mathrm{C}_{\mathrm{av}}$ & $\operatorname{Ir}-\mathrm{N}(1)^{a}$ & $\operatorname{Ir}-\mathrm{N}(2)^{a}$ & $\operatorname{Ir}-\mathrm{N}(3)^{b}$ & $\mathrm{Ir}-\mathrm{X}^{\mathrm{c}}$ \\
\hline 1 & $2.018(4)$ & $2.044(4)$ & $2.153(4)$ & $2.162(4)$ & $2.3458(11)$ \\
\hline 2 & $2.023(3)$ & $2.174(3)$ & $2.046(3)$ & $2.187(3)$ & $2.3586(8)$ \\
\hline$\overline{4}$ & $2.013(3)$ & $2.042(3)$ & $2.049(3)$ & $2.159(3)$ & $2.4395(8)$ \\
\hline 5 & $2.036(3)$ & $2.058(2)$ & $2.035(2)$ & $2.149(2)$ & $2.4241(6)$ \\
\hline 6 & $2.040(4)$ & $2.052(4)$ & $2.049(4)$ & $2.182(4)$ & $2.4476(11)$ \\
\hline 8 & $2.041(5)$ & $2.054(4)$ & $2.051(4)$ & $2.159(3)$ & $2.7440(3)$ \\
\hline 9 & $2.037(3)$ & $2.027(2)$ & $2.058(2)$ & $2.146(3)$ & $2.7336(2)$ \\
\hline \multicolumn{6}{|c|}{ Bond Angles $\left({ }^{\circ}\right)$} \\
\hline Complex & \multicolumn{2}{|c|}{$C(13)-I r-C(26)$} & $\mathrm{N}(1)-\mathrm{Ir}-\mathrm{N}(2)$ & \multicolumn{2}{|r|}{$N(3)-I r-X$} \\
\hline 1 & \multicolumn{2}{|c|}{$94.79(18)$} & $98.40(14)$ & \multicolumn{2}{|r|}{$90.74(10)$} \\
\hline 2 & \multicolumn{2}{|c|}{$92.48(13)$} & 98.91(10) & \multicolumn{2}{|r|}{$91.53(7)$} \\
\hline 4 & \multicolumn{2}{|c|}{$87.75(12)$} & $175.67(11)$ & \multicolumn{2}{|r|}{$91.12(7)$} \\
\hline 5 & \multicolumn{2}{|c|}{$87.14(10)$} & $176.71(8)$ & \multicolumn{2}{|r|}{$89.71(6)$} \\
\hline 6 & \multicolumn{2}{|c|}{$92.37(17)$} & $172.75(14)$ & \multicolumn{2}{|r|}{$89.17(10)$} \\
\hline 8 & \multicolumn{2}{|c|}{ 88.14(17) } & $174.35(14)$ & \multicolumn{2}{|r|}{$91.24(9)$} \\
\hline 9 & \multicolumn{2}{|c|}{$85.50(12)$} & $173.60(10)$ & \multicolumn{2}{|r|}{$92.59(7)$} \\
\hline
\end{tabular}

a the nitrogen of $\mathrm{C}^{\wedge} \mathrm{N}$ ligands; ${ }^{\mathrm{b}}$ the nitrogen of pyridine derivatives (NR). ${ }^{\mathrm{c}}$ the chlorine for complexes 1, 2, and 4-6, or iodine for complexes 8-9.

All of the complexes adopted distorted octahedral coordination geometry around the iridium. For complexes $\mathbf{1}$ and 2, the two $\mathrm{C}^{\wedge} \mathrm{N}$ ligands adopt a cis-C-C and a cis- $\mathrm{N}-\mathrm{N}$ chelate disposition, respectively, such that the bond lengths of the two $\operatorname{Ir}-\mathrm{N}_{\left(\mathrm{C}^{\wedge} \mathrm{N}\right)}$ are different from each other. The bond length of the $\operatorname{Ir}-\mathrm{N}_{\left(\mathrm{C}^{\wedge} \mathrm{N}\right)}$ trans to the carbon atom of the other one of the $\mathrm{C}^{\wedge} \mathrm{N}$ ligand is longer than that of the Ir- $\mathrm{N}_{\left(\mathrm{C}^{\wedge} \mathrm{N}\right)}$ trans to chlorine. For complex 1, the bond length of the $\operatorname{Ir}-\mathrm{N}(2)$ trans to the carbon is $2.153 \AA$, and the bond length of the $\mathrm{Ir}-\mathrm{N}(1)$ trans to the chlorine is $2.044 \AA$. In contrast, the two $\mathrm{C}^{\wedge} \mathrm{N}$ ligands of complexes 4-6 and 8-9 adopt a cis-C-C and a trans-N-N chelate disposition, respectively, and the bond lengths of the two $\mathrm{Ir}-\mathrm{N}_{\left(\mathrm{C}^{\wedge} \mathrm{N}\right)}$ are similar.

A thermal gravimetric analysis (TGA) was used to evaluate the thermal stability of complexes 1-9, and the weight losses (\%) for complexes 1-9 under a specific temperature are listed in Table 2. It is shown that, for all of the complexes, the NR group was the first group to be released. The temperature when the NR group was completely lost is denoted as $\mathrm{TD}_{\mathrm{NR}}$.

Table 2. Thermal gravimetric analysis (TGA) Data of Complexes 1-9.

\begin{tabular}{|c|c|c|c|c|c|c|c|c|c|}
\hline Para. Complex & 1 & 2 & 3 & 4 & 5 & 6 & 7 & 8 & 9 \\
\hline $\mathrm{MW}^{\mathrm{a}}$ & 695 & 709 & 719 & 768 & 781 & 791 & 859 & 873 & 884 \\
\hline$W_{\mathrm{NR}}{ }^{\mathrm{b}}$ & 11.4 & 13.1 & 14.5 & 10.3 & 11.9 & 13.2 & 9.2 & 10.7 & 11.8 \\
\hline $\mathrm{TD}_{\mathrm{NR}}{ }^{\mathrm{c}}$ & 251 & 220 & 200 & 297 & 360 & 237 & 180 & 289 & 326 \\
\hline
\end{tabular}

a molecular weight of complex, ${ }^{b}$ weight percentage of NR group for complex, ${ }^{c}$ the temperature at which the NR group was completely lost.

As shown in Table 2, all of the complexes are quite thermostable, among which complex 5 is the most stable, with a very high decomposing temperature $\left(\mathrm{TD}_{\mathrm{NR}}=360^{\circ} \mathrm{C}\right)$. For the complexes with the same type of NR and halogen ligands, complexes possessing ligand dfpbo are more stable than those with pbo, which demonstrates that the cyclometalating ligand dfpbo stabilizes the structure better than pbo.

\subsection{Oxidation of Toluene with Dioxygen}

Although complexes 1-9 are inert and quite stable in solid state, they release an active structure in solution. For example, under air, the toluene solution of complex 4 has a weak electron paramagnetic 
resonance (EPR) signal at room temperature (Figure 2a), and shows a much stronger signal at higher temperature $\left(80^{\circ} \mathrm{C}\right)$ (Figure $2 \mathrm{~b}$ ). The EPR spectrum of compound 4 displays an isotropic signal at $g=1.9116$, which is characteristic of an organic centered radical.

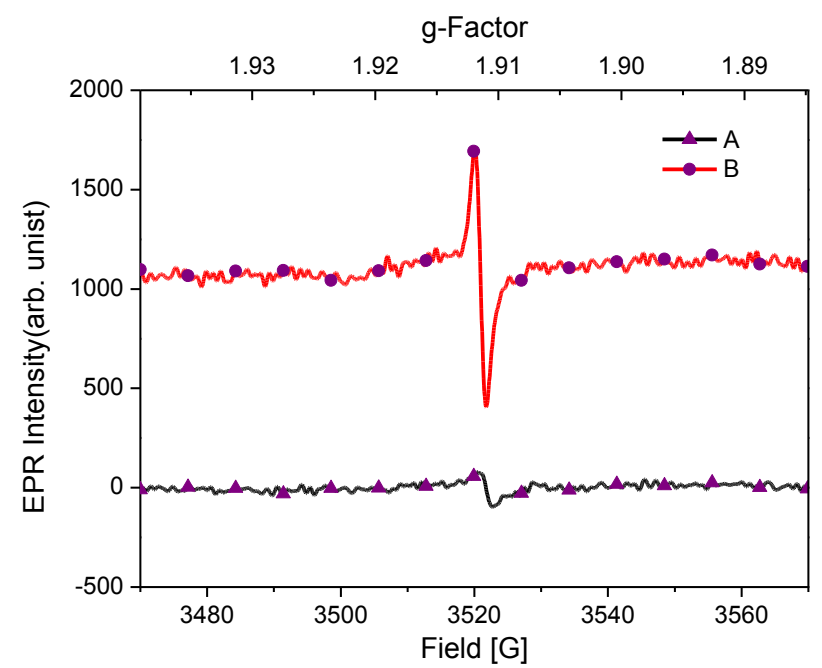

Figure 2. Electron paramagnetic resonance (EPR) spectra of complex 4 in toluene under air at (a) $298 \mathrm{~K}$, and (b) $353 \mathrm{~K}$. EPR settings: microwave frequency, $9.879 \mathrm{GHz}$; microwave power, $10.080 \mathrm{~mW}$; number of scans, 1.

When the toluene solution of complexes 1-9 were heated up to $100{ }^{\circ} \mathrm{C}$, after $2 \mathrm{~h}$ of reaction time, a major product benzaldehyde was formed. This product was identified by HPLC, UV, IR, and GCMS. The concentration of benzaldehyde increased very quickly in the reaction. When $0.1 \mathrm{mM}$ of complex 4 was loaded to the reaction system, the concentration of benzaldehyde became $577 \mathrm{mM}$ after $12 \mathrm{~h}$ of reaction time and the turnover number (TON) reached 5779 (Figure 3), which implies that complexes 1-9 produced a high reactive species in solution and catalytically converted toluene to benzaldehyde.

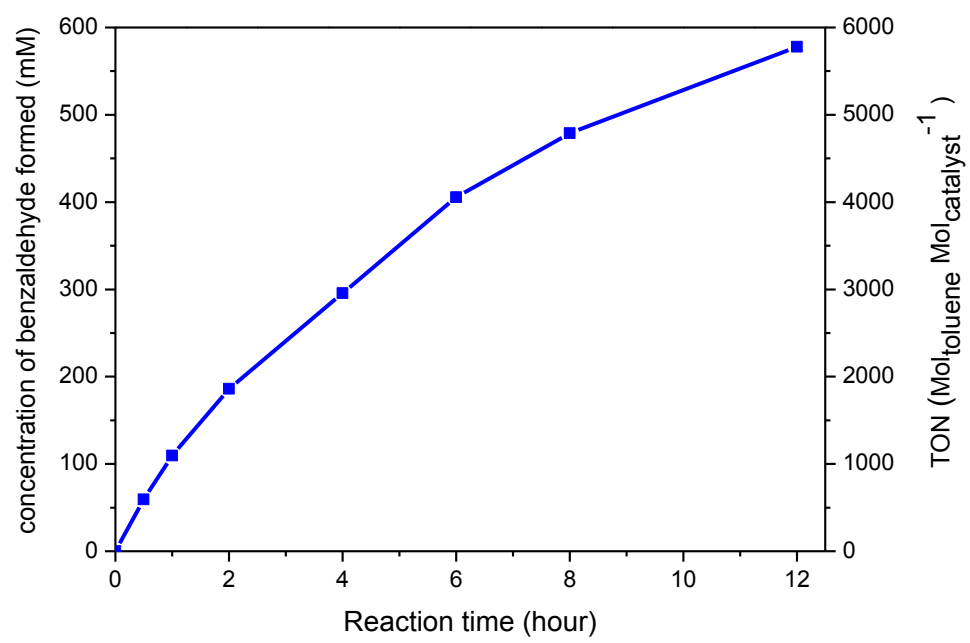

Figure 3. Reaction progress for the oxidation of neat toluene with $0.1 \mathrm{mM}$ of complex 4 as catalyst at a reaction temperature of $100{ }^{\circ} \mathrm{C}$.

It is noticeable that an undesired reaction occurred when a higher concentration of complexes 1-9 was used. When $100 \mathrm{mM}$ of complex 4 in toluene solution was heated to $100{ }^{\circ} \mathrm{C}$, some precipitate gradually formed, and one compound in the solution could also be found. The compound formed in the solution was identified as pyridine, and the precipitate has also been isolated and characterized as cyclometalated chloro-bridged iridium dimer (D2) (Figures S1b-S3b) by NMR (Figure S1a), 
IR (Figure S2a), and MS (Figure S3a). Therefore, in solution, complex 4 released the monodentate ligand, pyridine, to generate coordinatively unsaturated structure $\left[\left(\mathrm{C}^{\wedge} N\right)_{2} \operatorname{Ir}(\mathrm{Cl})\right]$ with a vacant site, which combine with each other to form the iridium dimer when complex 4 was used in a high concentration (Scheme 2).
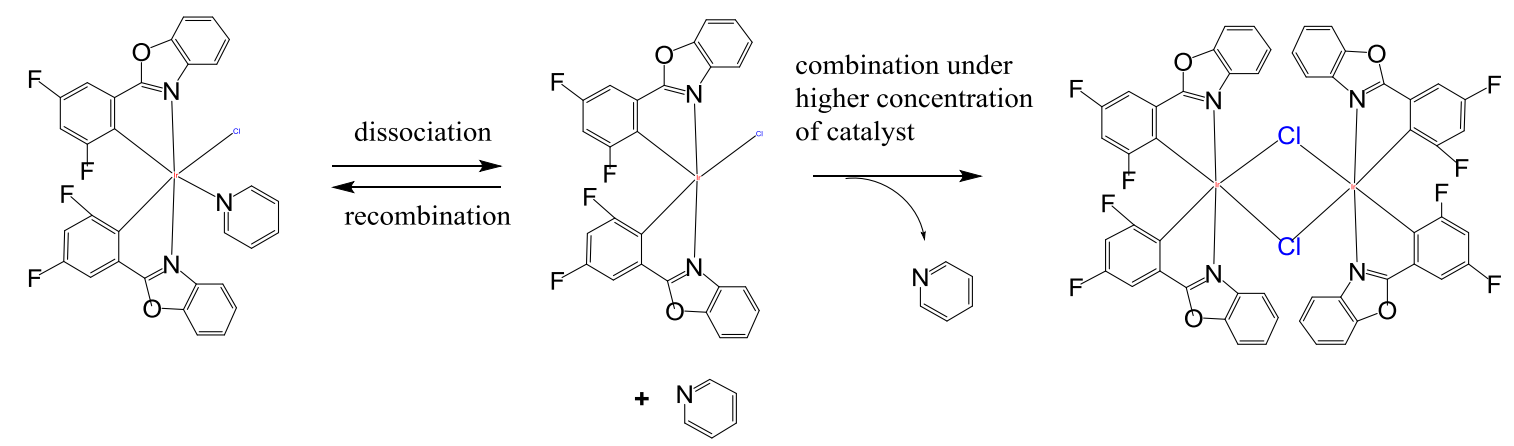

Scheme 2. The combination of two unsaturated structures $\left[(\mathrm{dfpbo})_{2} \operatorname{Ir}(\mathrm{Cl})\right]$ to form a chloro-bridged iridium dimer $\left[(\mathrm{dfpbo})_{2} \operatorname{Ir}(\mu-\mathrm{Cl})_{2} \operatorname{Ir}(\mathrm{dfpbo})_{2}\right]$.

Although the iridium dimer can also form a coordinatively unsaturated structure $\left[\left(\mathrm{C}^{\wedge} \mathrm{N}\right)_{2} \operatorname{Ir}(\mathrm{Cl})\right]$ in solution, the percentage of the $\left[\left(\mathrm{C}^{\wedge} N\right)_{2} \operatorname{Ir}(\mathrm{Cl})\right]$ resulting from the dissociation of the iridium dimer is minor, because the solubility of the iridium dimer is low, and the structure of the dimer is quite stable in solution. Therefore, complexes 1-9 cannot be loaded to the reaction system by too high concentration.

On the basis of previous reports on oxyfunctionalization by metal oxo compounds [33-36], a plausible catalytic cycle has been proposed (Scheme 3 ), including (a) complexes $\left[\left(C^{\wedge} N\right)_{2} \operatorname{Ir}(N R)(X)\right]$ releasing monodentate ligand $\mathrm{NR}$ to form a coordinatively unsaturated structure $\left[\left(\mathrm{C}^{\wedge} \mathrm{N}\right)_{2} \operatorname{Ir}(\mathrm{Cl})\right]$ with a vacant site [33]; (b) the nucleophilic addition reaction of $\mathrm{O}_{2}$ to $\left[\left(\mathrm{C}^{\wedge} \mathrm{N}\right)_{2} \mathrm{Ir}(\mathrm{Cl})\right]$ generating the iridium dioxygen adduct, $\left[\left(\mathrm{C}^{\wedge} N\right)_{2} \operatorname{Ir}(\mathrm{Cl})\left(\mathrm{O}_{2}\right)\right][34] ;(\mathrm{c})\left[\left(\mathrm{C}^{\wedge} \mathrm{N}\right)_{2} \operatorname{Ir}(\mathrm{Cl})\left(\mathrm{O}_{2}\right)\right]$ then reacting with another molecule of $\left[\left(\mathrm{C}^{\wedge} \mathrm{N}\right)_{2} \operatorname{Ir}(\mathrm{Cl})\right]$ to construct the $\mu$-peroxo complex $\left[\left(\mathrm{C}^{\wedge} \mathrm{N}\right)_{2}(\mathrm{Cl}) \operatorname{Ir}\left(\mu-\mathrm{O}_{2}\right) \operatorname{Ir}(\mathrm{Cl})\left(\mathrm{C}^{\wedge} \mathrm{N}\right)_{2}\right][34-36]$; (d) homogenous cleavage of the $\mathrm{O}-\mathrm{O}$ bond in $\left[\left(\mathrm{C}^{\wedge} \mathrm{N}\right)_{2}(\mathrm{Cl}) \operatorname{Ir}\left(\mu-\mathrm{O}_{2}\right) \operatorname{Ir}(\mathrm{Cl})\left(\mathrm{C}^{\wedge} \mathrm{N}\right)_{2}\right]$ resulting in two oxo iridium complexes $\left[\left(\mathrm{C}^{\wedge} \mathrm{N}\right)_{2}(\mathrm{Cl}) \operatorname{Ir}(\mathrm{O})\right]$ [34]; (e) coordination of a toluene to oxo iridium complex $\left[\left(\mathrm{C}^{\wedge} \mathrm{N}\right)_{2}(\mathrm{Cl}) \operatorname{Ir}(\mathrm{O})\right]$; (f) $\beta$-hydrogen transfer and oxidative addition to form complex $\left[\left(\mathrm{C}^{\wedge} \mathrm{N}\right)_{2}(\mathrm{Cl}) \mathrm{Ir}(\mathrm{OH})\left(\mathrm{C}_{6} \mathrm{H}_{5} \mathrm{CH}_{2}\right)\right] ;(\mathrm{g})$ reductive elimination to regenerate a coordinatively unsaturated structure $\left[\left(\mathrm{C}^{\wedge} \mathrm{N}\right)_{2} \operatorname{Ir}(\mathrm{Cl})\right]$ and benzyl alcohol; $(\mathrm{h})$ the geminal diol being unstable and able to easily eliminate water to produce benzaldehyde.

\subsection{Chemical Kinetics}

To evaluate the catalytic ability of the complexes, complexes 1-9 were applied to the catalytic oxidation of toluene under various experimental conditions. The reaction solution was stirred well under air to keep the concentration of oxygen constant, and the calibration curve of the standard solutions containing toluene and benzaldehyde was used to monitor the progress of the reactions (Figures S4-S6). The reaction rates are summarized in Table S4, and the rate constants ( $k$ ) and activation energies (Ea) are summarized in Table S5. The reaction rates of those reactions are also shown in Figure 4. The rate constants are shown in Figure 5. 


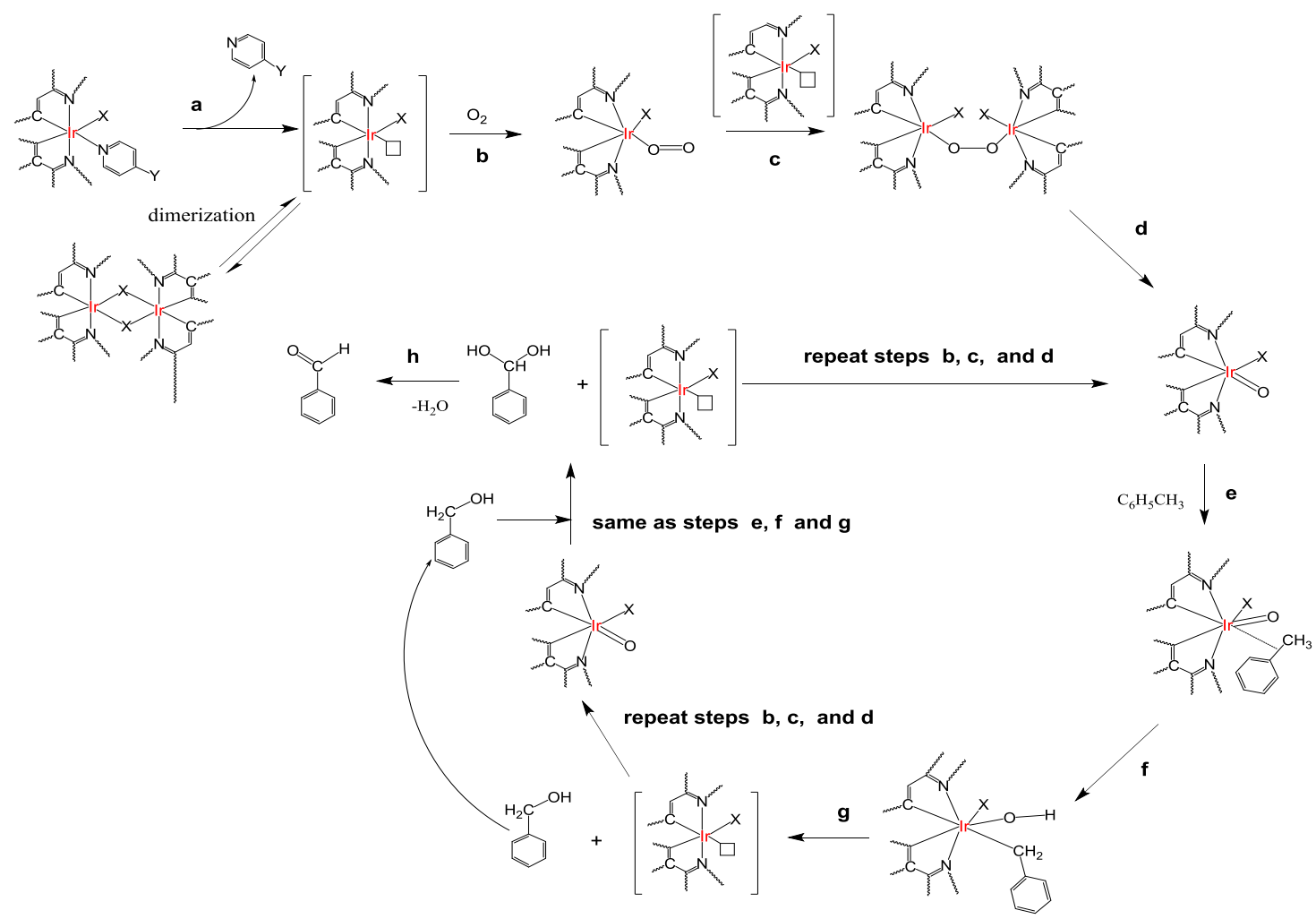

Scheme 3. Proposed mechanism for the formation of benzaldehyde, including a coordinatively unsaturated structure $\left[\left(\mathrm{C}^{\wedge} \mathrm{N}\right)_{2} \operatorname{Ir}(\mathrm{Cl})\right]$ with a vacant site.
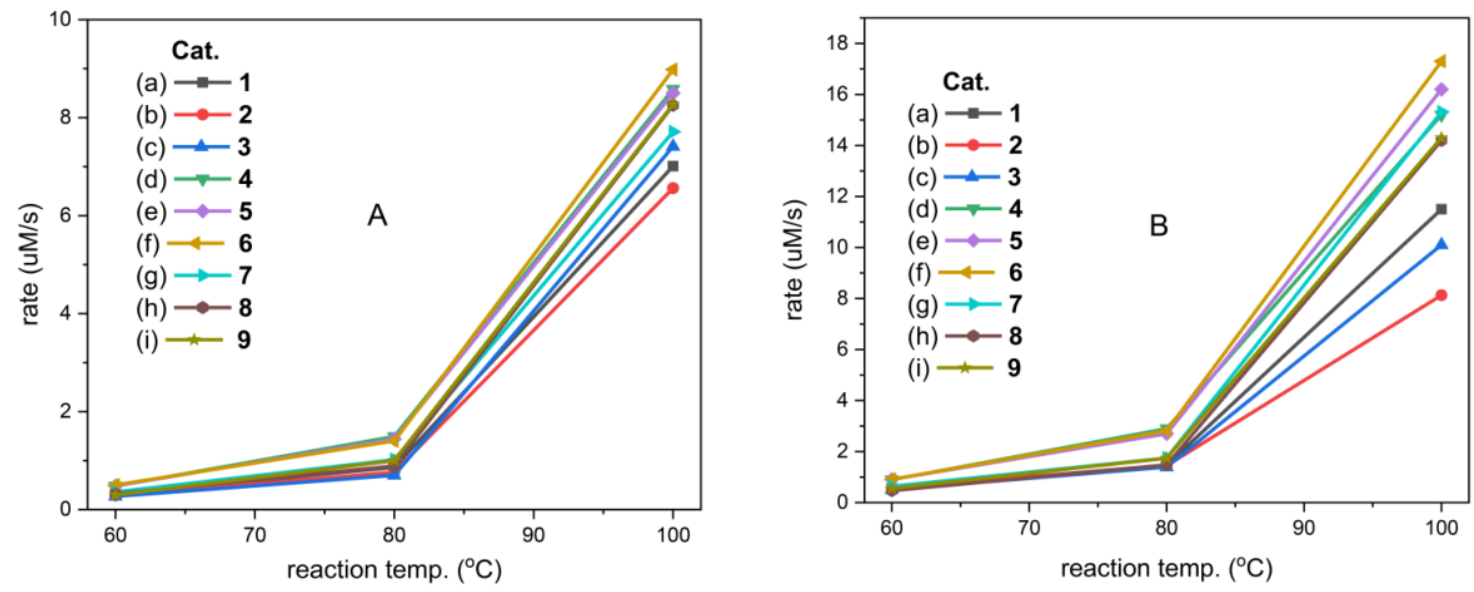

Figure 4. Cont. 

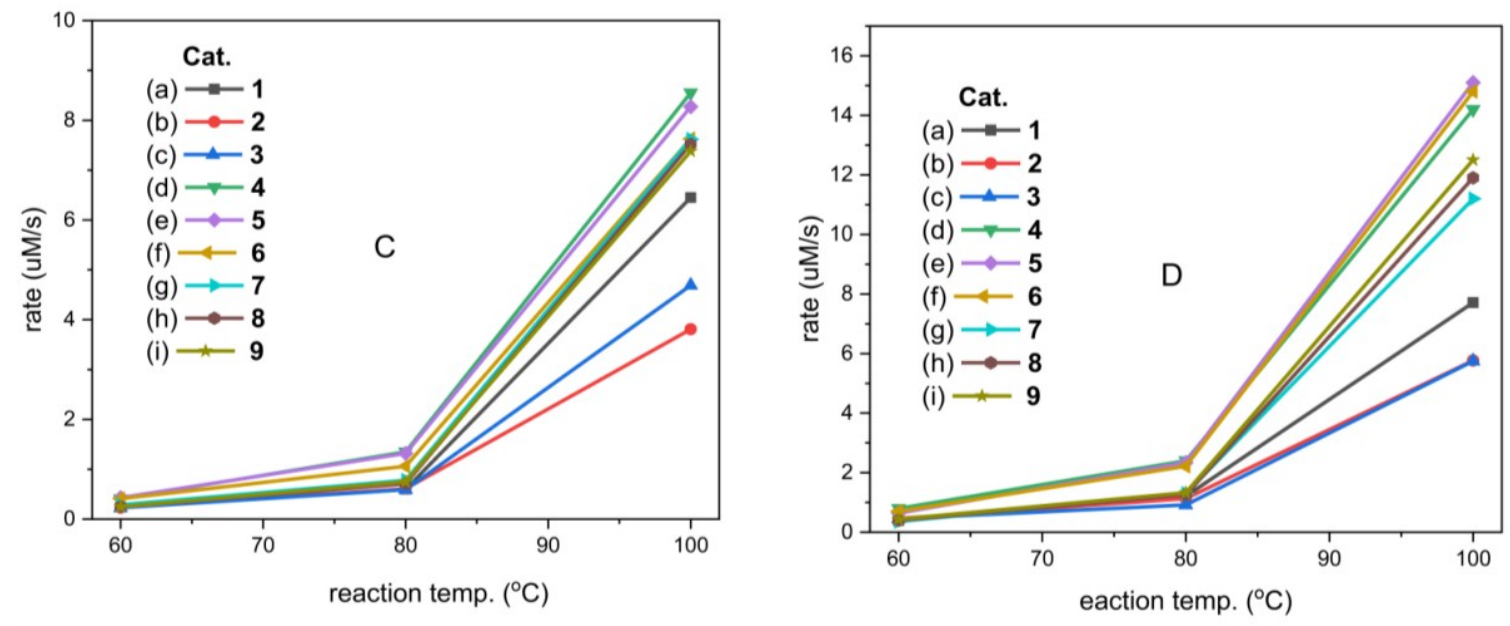

Figure 4. Reaction rate $(\mu \mathrm{M} / \mathrm{s})$ for the catalytic oxidation of (A) $0.1 \mathrm{mM}$ of catalyst in neat toluene ([toluene] $=9.39 \mathrm{M}) ;(\mathbf{B}) 0.2 \mathrm{mM}$ of catalyst in neat toluene ([toluene] $=9.39 \mathrm{M}) ;(\mathbf{C}) 0.1 \mathrm{mM}$ of catalyst in a reaction solution consisting of $80 \%$ of toluene and $20 \%$ of 1,2-dichlorobenzene $(v / v)$ ([toluene] $=7.51 \mathrm{M}$ ); and (D) $0.2 \mathrm{mM}$ of catalyst in a reaction solution consisted of $80 \%$ of toluene and $20 \%$ of 1,2-dichlorobenzene.

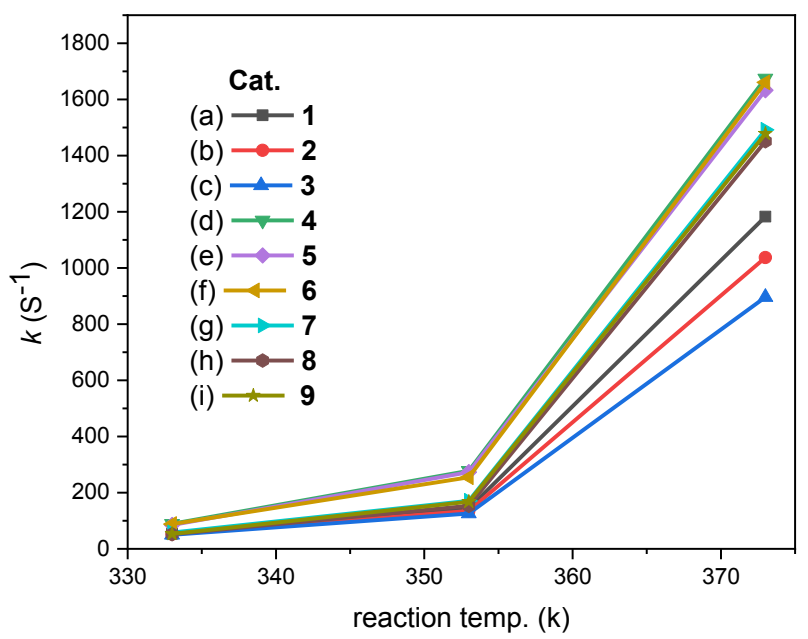

Figure 5. Rate constants of the catalytic oxidation for toluene.

According to the experimental data in Figures 4 and 5, it is realized that there is some relationship between the $\mathrm{CHA}$ activity and the structural property. For example, at $80^{\circ} \mathrm{C}$, the rate constants of 1-6 $\left(k^{353}\right)$ are $1.44 \times 10^{-4}, 1.35 \times 10^{-4}, 1.26 \times 10^{-4}, 2.78 \times 10^{-4}, 2.73 \times 10^{-4}$, and $2.55 \times 10^{-4} \mathrm{~s}^{-1}$, respectively, indicating that for complexes possessing the same monodentate ligands (halide and NR ligands), the rate constants of the complexes containing the dfpbo ligand (4-6) are about two times of those containing the pbo ligand (1-3).

Through comparing the rate constants of complexes 1-3 with those of complexes 7-9 $\left(k^{353}\right.$ are $1.71 \times 10^{-4}, 1.53 \times 10^{-4}$, and $1.68 \times 10^{-4} \mathrm{~s}^{-1}$, respectively), we find that although the halide ligand affects catalytic ability, the influence resulting from dfpbo cannot be underestimated. Therefore, we can see that if there are electron-withdrawing groups (EWG) on the bidentate ligand (the phenylbenzoxazole group, $\mathrm{C}^{\wedge} \mathrm{N}$ ), the catalytic ability of the iridium complex is apparently improved (Figure 5), which can be attributed to two effects. The first effect is that the dfpbo ligand is less $\sigma$ basic than the pbo ligand, because the EWG on the $C^{\wedge} N$ ligand lowers the capability of electron donation from the monoanionic cyclometalating ligand to the central metal atom, and the other one is that the EWG on the $C^{\wedge} N$ ligand can promote the $\pi$ acidity of the $C^{\wedge} N$ ligand and enhance the metal to $\mathrm{C}^{\wedge} \mathrm{N} \pi^{*}$ back bonding. Both effects can reduce the electron density on the iridium, and consequently, 
the complexes with a higher partial positive charge on the metal become better electrophiles, and can attract the electron donor better, and hence promote nucleophilic addition reaction.

The normalized X-Ray absorption near-edge structure (XANES) spectra at the Ir L3-edge (Figure 6) also shows that the complexes with dfpbo ligands (Figure $6 \mathrm{~b}, \mathrm{c}$ ) have a higher partial positive charge on the iridium atom than the complexes with pbo ligands do (Figure 6a).

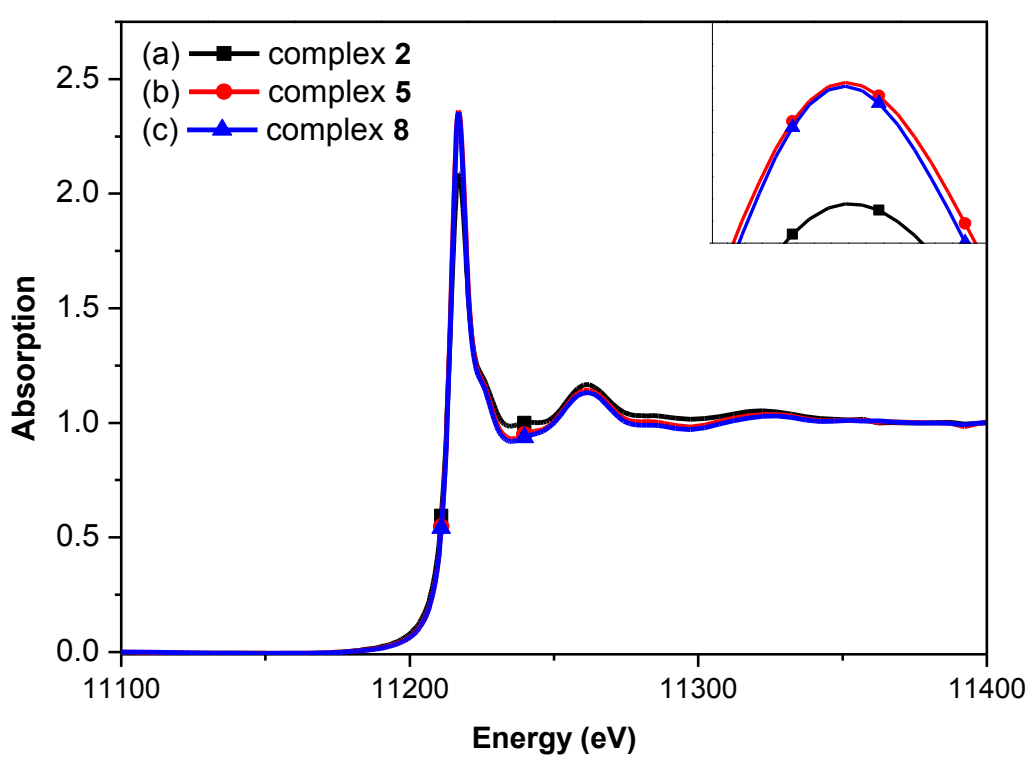

Figure 6. Ir L3-edge X-ray absorption near-edge structure (XANES) of crystalline (a) $\left[(\mathrm{pbo})_{2} \mathrm{Ir}^{\mathrm{III}}(\mathrm{Cl})(4 \mathrm{mpy})\right](2) ;(\mathbf{b})(\bullet)\left[(\mathrm{dfpbo})_{2} \mathrm{Ir}^{\mathrm{III}}(\mathrm{Cl})(4 \mathrm{mpy})\right](5)$, and (c) $(\boldsymbol{\Lambda})\left[(\mathrm{dfpbo})_{2} \mathrm{Ir}^{\mathrm{III}}(\mathrm{I})(4 \mathrm{mpy})\right](\mathbf{8})$.

Complexes 7-9 have the same bidentate ligands as complexes 4-6, but their rate constants are only about $60 \%$ of those of $4-6$, indicating that the chloroiridium complexes have a better catalytic activity than the iodoiridium ones. Two factors involving the electronegativity (EN) and the size of the halide ligands are in charge of the difference. The electronegativity of iodine (2.7) is less than that of chlorine (3.0), such that the partial positive charges on the iridium atoms of complexes 7-9 are smaller than those of complexes 4-6, which led to a decrease in the reactivity of complexes 7-9. Moreover, the atomic size of iodine is greater than that of chlorine, and the bulkier group near the active site of the intermediates encumbers the approach of reactants.

As shown in Table S5, for complexes composed of the same kind of $\mathrm{C}^{\wedge} \mathrm{N}$ and halogen ligands, the complexes with a lower activation energy (EA) have a higher rate constant. The activation energies that are needed for the catalytic oxidation of toluene by using complexes 1-9 as catalysts are summarized in Figure 7.

In general, the dissociation energy of a $\mathrm{C}-\mathrm{H}$ in the benzylic position of toluene is $88 \mathrm{kcal} / \mathrm{mol}$, which is a robust chemical bond. To functionalize hydrocarbons, some active reactants should be used to supply the chemical energy in most cases, and some stoichiometric amounts of materials should be supplied to the systems. However, by using cyclometalated iridium complexes as catalysts, an environmentally-friendly process can be used to produce benzaldehyde with a low activation energy $(\sim 30 \mathrm{kcal} / \mathrm{mol})$. 


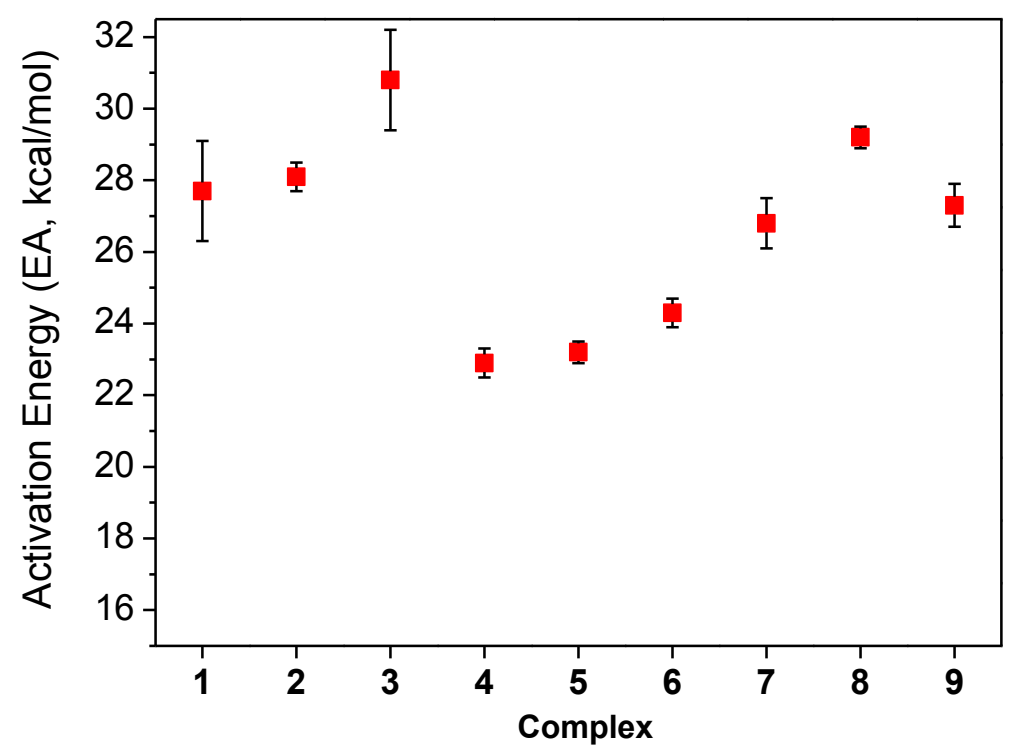

Figure 7. Activation energy $(\mathrm{EA}, \mathrm{kcal} / \mathrm{mol})$ for the catalytic oxidation of neat toluene by using $0.1 \mathrm{mM}$ of complexes 1-9 as catalysts at $100{ }^{\circ} \mathrm{C}$ of reaction temperature.

\subsection{Performance on Catalytic Oxidation}

By using the complexes as catalysts, the activation energy that is needed for the catalytic oxidation of toluene is lowered, and the reaction rates increase rapidly when the reaction temperature is raised. The reaction progress for the catalytic oxidation of toluene with complexes 1-9 as catalysts at various reaction temperatures is represented in Figure 8, which shows that the catalytic rates of the complexes at $100{ }^{\circ} \mathrm{C}$ are about seven times those at $80{ }^{\circ} \mathrm{C}$. When $0.1 \mathrm{mM}$ of complexes 1-3 was used for the reactions at $100{ }^{\circ} \mathrm{C}$, the catalytic rates of the catalytic oxidation are $7.50,7.28$, and $6.77 \mu \mathrm{M} \mathrm{s}^{-1}$, respectively, and the concentrations of the product after $6 \mathrm{~h}\left(\mathrm{CP}_{6}\right)$ are 162,157 , and $146 \mathrm{mM}$, respectively.

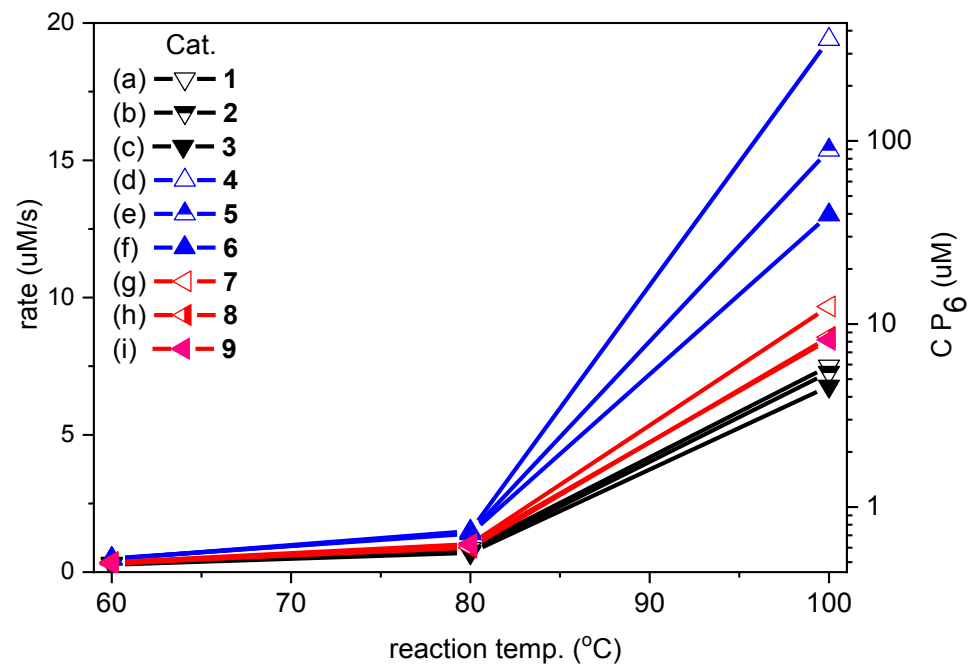

Figure 8. Reaction rate $(\mu \mathrm{M} / \mathrm{s})$ and the concentration of benzaldehyde accumulated after $6 \mathrm{~h}$ of reaction time $\left(\mathrm{CP}_{6}, \mathrm{mM}\right)$ for the catalytic oxidation of neat toluene: $0.1 \mathrm{mM}$ of complexes 1-9 were used as catalysts in various reaction temperatures.

For complexes 4-6, the catalytic rates are $19.4,15.4$, and $13.0 \mu \mathrm{M} \mathrm{s}^{-1}$, respectively, and the $\mathrm{CP}_{6}$ are 419,332 , and $281 \mathrm{mM}$, respectively. For complexes 7-9, the catalytic rates are 9.67, 8.56, and $8.46 \mu \mathrm{M} \mathrm{s}^{-1}$, respectively and the $\mathrm{CP}_{6}$ are 209,185 , and $183 \mathrm{mM}$, respectively. The results show that all of the complexes reported here are powerful catalysts for the catalytic oxidation of toluene. 
After $6 \mathrm{~h}$, the concentration of product resulting from catalytic oxidation reaches 4000 times the concentration of the catalyst applied. The turnover frequency (TOF) of the complexes for catalytic oxidation reached $698 \mathrm{~h}^{-1}$, which are quite good performances for the transformation of toluene, and much better than previous reports [37-40]. The performances of complexes 7-9 for the catalytic oxidation of toluene are shown in Table 3, and compared with some previous reports.

Table 3. Reaction Conditions of Catalytic Oxidation for Toluene.

\begin{tabular}{|c|c|c|c|c|c|}
\hline Entry & Conversion ${ }^{d}(\%)$ & Selectivity ${ }^{\mathrm{e}}(\%)$ & TON $^{f}$ & TOF $\left(h^{-1}\right) g$ & Quantum Yield ${ }^{\text {h }}$ \\
\hline $\mathrm{g}-\mathrm{C}_{3} \mathrm{~N}_{4}{ }^{\mathrm{a}}$ & 2.6 & 24 & 4.7 & 0.29 & - \\
\hline $\operatorname{mpg} 130^{a}$ & 2.6 & 99 & 23.1 & 1.44 & - \\
\hline$\left[\mathrm{UO}_{2}{ }^{2+}\right]^{\mathrm{b}}$ & $<1$ & 30 & - & - & 0.01 \\
\hline $\mathrm{NaBr} \mathrm{c}^{\mathrm{C}}$ & 10 & 40 & $<1$ & $<0.25$ & - \\
\hline Complex 1 & 1.73 & 90 & 1620 & 270 & - \\
\hline Complex 2 & 1.67 & 90 & 1580 & 262 & - \\
\hline Complex 3 & 1.55 & 90 & 1460 & 244 & - \\
\hline Complex 4 & 4.46 & 96 & 4180 & 698 & - \\
\hline Complex 5 & 4.66 & 97 & 3320 & 553 & - \\
\hline Complex 6 & 3.44 & 96 & 2810 & 468 & - \\
\hline Complex 7 & 2.23 & 95 & 2090 & 349 & - \\
\hline Complex 8 & 1.97 & 94 & 1850 & 308 & - \\
\hline Complex 9 & 1.95 & 93 & 1830 & 304 & - \\
\hline
\end{tabular}

${ }^{a}$ Li et al. [37]; ${ }^{b}$ Mao et al. [39]; ${ }^{c}$ Borgaonkar et al. [40]; ${ }^{d}$ conversion of toluene to benzaldehyde; ${ }^{\mathrm{e}}$ the chemoselectivity to benzaldehyde; ${ }^{\mathrm{f}}$ the turnover number after $6 \mathrm{~h}$ of reaction time; ${ }^{\mathrm{g}}$ catalytic frequencies of the complexes $\left(\mathrm{h}^{-1}\right) ;{ }^{\mathrm{h}}$ for the photocatalytic oxidation of toluene to benzaldehyde.

To investigate the concentration effect of the catalysts on the catalytic oxidation of toluene, complexes 1-9 were loaded to the reaction system in various concentrations between $1.0 \times 10^{1}$ and $1.0 \times 10^{-3} \mathrm{mM}$, and the experimental data are summarized in Table S6. The reaction temperature was $100{ }^{\circ} \mathrm{C}$, and the reaction time was $6 \mathrm{~h}$. The catalytic rate of complexes, catalytic frequencies, the concentration of the product after $6 \mathrm{~h}$ of reaction time, and the chemoselectivity to benzaldehyde are also shown in Figure 9.

For complexes 1-3 and 7-9, the maximum reaction rate for catalytic oxidation appeared when $0.1 \mathrm{mM}$ of the complex was used. The maximum catalytic rates for $0.1 \mathrm{mM}$ of complexes 1-3 are between 6.77 and $7.50 \mu \mathrm{M} \mathrm{s}^{-1}$, and those of $0.1 \mathrm{mM}$ of complexes 7-9 are between 8.46 and $9.67 \mu \mathrm{M} \mathrm{s}^{-1}$, which show that complexes 7-9 have higher catalytic rates than complexes 1-3 by $\sim 28 \%$. The effect of the bidentate ligand on catalytic oxidation is thus more important than that of the halide ligand. When complexes 1-3 and 7-9 were loaded to the reaction system with a concentration lower than $0.1 \mathrm{mM}$, the reaction rates decreased, but the turnover frequency (TOF) and the turnover number $\left(\mathrm{TON}_{6}\right)$ increased, which imply that when a lower concentration of the complexes was used, the formation rate of benzaldehyde become lower, but the ratio of catalytically active species became higher in solution. For these complexes, the maximum catalytic frequency and the turnover number reached $4880 \mathrm{~h}^{-1}$ and 29,220 , respectively, which showed that these catalysts are very active. Moreover, when complexes 1-3 and 7-9 were loaded to the reaction system with a concentration higher than $0.1 \mathrm{mM}$, all of the reaction rates, catalytic frequencies, and the turnover number decreased, which is because the combination of $\left[\left(\mathrm{C}^{\wedge} \mathrm{N}\right)_{2} \operatorname{Ir}(\mathrm{Cl})\right]$ to form the iridium dimers became obvious, and the combination of $\left[\left(\mathrm{C}^{\wedge} \mathrm{N}\right)_{2} \operatorname{Ir}(\mathrm{Cl})\right]$ gradually dominated the reaction. 

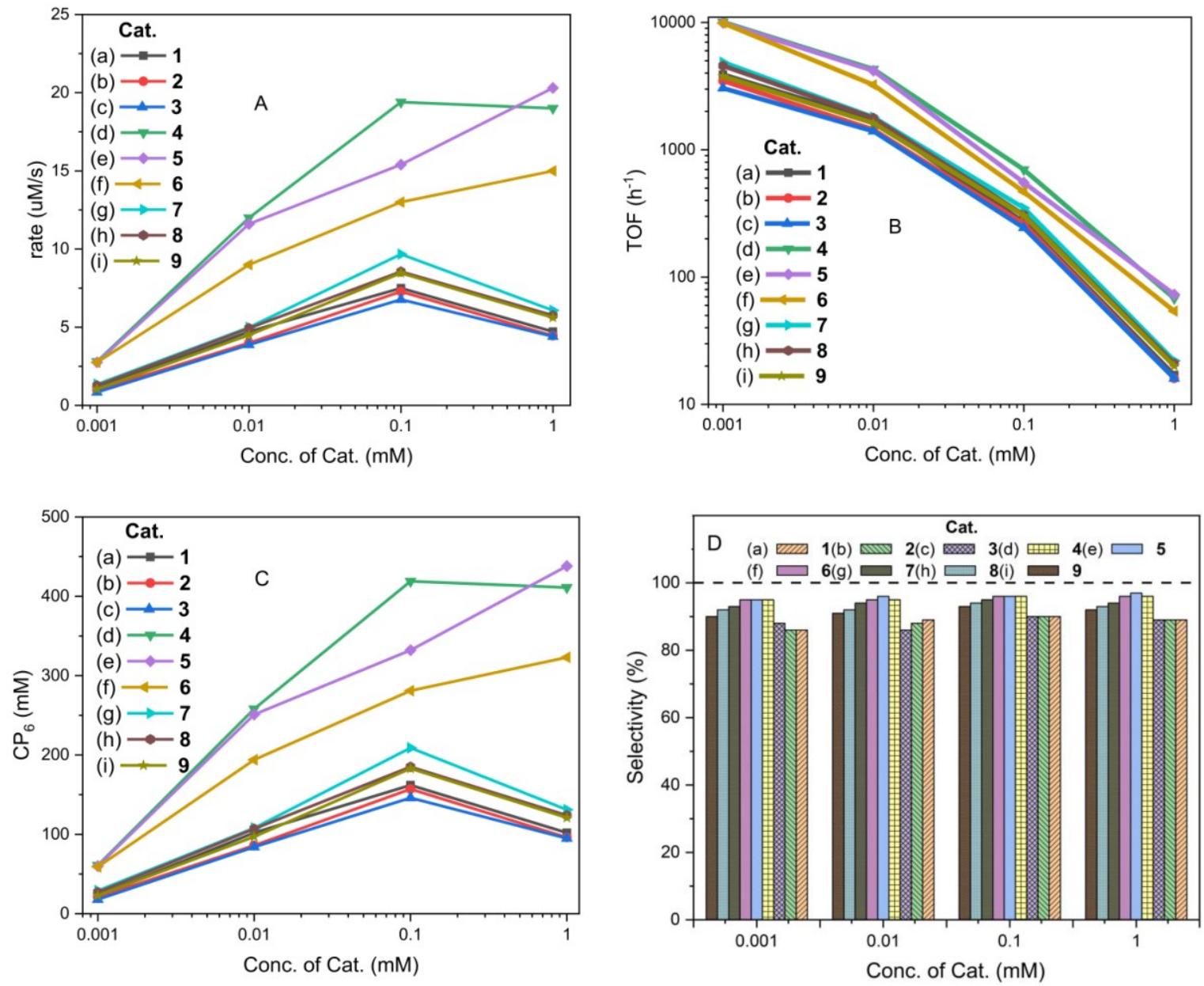

Figure 9. Catalytic oxidation of toluene, complexes 1-9 were loaded to the reaction system in various concentrations between $1.0 \times 10^{1}$ and $1.0 \times 10^{-3} \mathrm{mM}$. (A) The catalytic rate of complexes for the catalytic oxidation of toluene $\left(\mu \mathrm{M} \mathrm{s}^{-1}\right)$; (B) the catalytic frequencies; (C) the concentration of the product after $6 \mathrm{~h}$ of reaction time $(\mathrm{mM})$; and (D) the chemoselectivity to benzaldehyde.

For complexes 4-6, the maximum reaction rate for catalytic oxidation appeared when $0.1 \sim 1.0 \mathrm{mM}$ of the complex was used. This concentration is higher than that of complexes 1-3 and 7-9 due to two factors. The first is that the combination of the coordinatively unsaturated structure $\left[\left(\mathrm{C}^{\wedge} \mathrm{N}\right)_{2} \operatorname{Ir}(\mathrm{Cl})\right]$ to form an iridium dimer $\left[\left(\mathrm{C}^{\wedge} \mathrm{N}\right)_{2} \operatorname{Ir}(\mathrm{Cl})\right]_{2}$ for complexes 1-3 and 7-9 is much easier than that for complexes 4-6, while the other is that the reactive species resulting from complexes 4-6 are much more active than those from complexes 1-3 and 7-9. Overall, the effect resulting from the activation of complexes 4-6 can override the effect resulting from the combination of $\left[\left(\mathrm{C}^{\wedge} \mathrm{N}\right)_{2} \operatorname{Ir}(\mathrm{Cl})\right]$, which allow complexes 4-6 to be applied to the reaction system at a higher concentration. For complexes 4-6, the maximum catalytic rate, catalytic frequency, and the turnover number reach $20.3 \mu \mathrm{M} \mathrm{s}^{-1}, 9940 \mathrm{~h}^{-1}$, and 59,600 , respectively.

The chemoselectivity to benzaldehyde is slightly dependent upon the concentrations of the catalysts that are used, but it is obviously affected by the structure of bidentate cyclometalating ligands $\left(\mathrm{C}^{\wedge} \mathrm{N}\right)$, and among them, $97 \%$ of selectivity could be achieved. The chemoselectivity of the complexes, due to the different coordination ability to benzyl alcohol and benzaldehyde, can easily oxidize benzyl alcohol to benzaldehyde, but can hardly transform benzaldehyde into benzoic acid; therefore, the catalytic cycle stops at the step forming benzaldehyde. A comparison of the conversions by using complex 4 as the catalyst (Figure 10) reveals that the conversion of benzyl alcohol to benzaldehyde is much faster than the transformation of benzaldehyde into benzoic acid. 


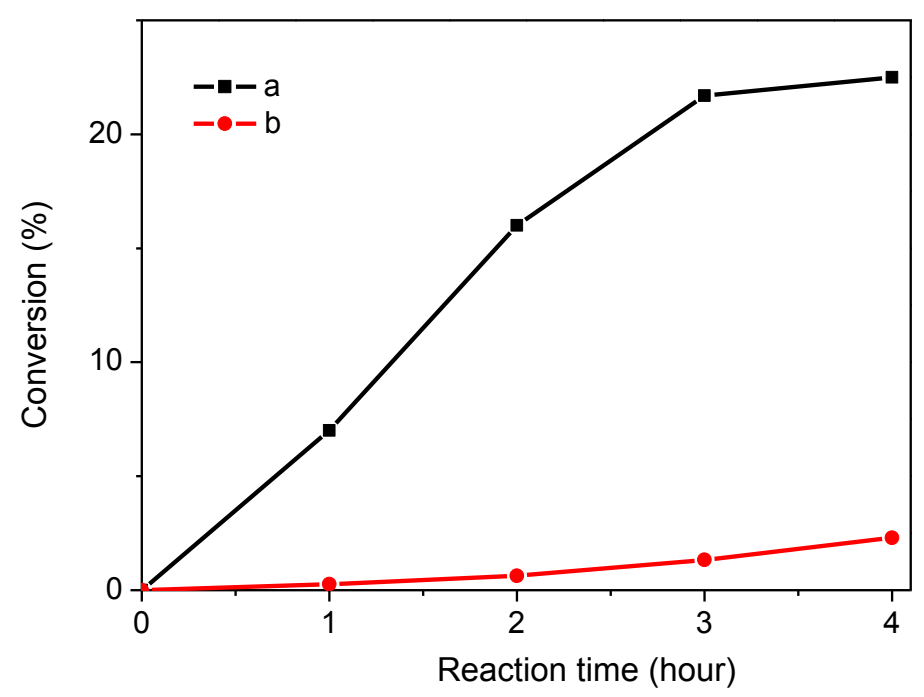

Figure 10. Reaction progress for the catalytic oxidation of (a) benzyl alcohol and (b) benzaldehyde at $100{ }^{\circ} \mathrm{C}$ of reaction temperature. The concentration of benzyl alcohol and benzaldehyde is $5 \mathrm{M}$ in toluene. First, $5 \mathrm{mM}$ of complex 4 was applied to the reactions. The conversion was measured by HPLC for the transformation of benzyl alcohol into benzaldehyde and for benzaldehyde into benzoic acid.

\section{Experimental Section}

\subsection{Materials and Methods}

Solvents were dried and deoxygenated by refluxing over the appropriate reagents before use. 3,5-Difluorobenzoic acid was purchased from Matrix (Sevelen, Switzerland), and $\operatorname{IrCl}_{3} \cdot n \mathrm{H}_{2} \mathrm{O}$ was obtained from the Seedchem Co. (Melbourne, Australia). All other chemicals, including 2-phenylpyridine, were purchased from Acros (Geel, Belgium) and used as received. NMR spectra were measured on a Bruker AVIIIHD-600 MHz or a Mercury 300 MHz NMR spectrometer (Varian, Palo Alto, CA, USA). UV-vis spectra were obtained using a Hitachi U-3900 Spectrophotometer (Hitachi, Tokyo, Japan). The infrared spectra were recorded on Agilent Technologies Model Cary 630 FTIR instruments (Agilent Technologies, Santa Clara, CA, USA). Mass spectra were taken with a Finnigan/Thermo Quest MAT 95XL instrument (Scientific Instrument Service Inc., Ringoes, NJ, USA) with electron impact ionization for organic compounds or fast atom bombardment for metal complexes.

\subsection{Synthetic Procedures}

\subsubsection{Synthesis of Ligands and Cyclometalated Ir(III) Chloro-Bridged Dimers (D1 and D2)}

Ligands including 2-phenylbenzoxazol and 2-(3,5-difluorophenyl)benzoxazole (dfpbo) were prepared by Phillips condensation, as described in our previously reported procedure. The cyclometalated $\operatorname{Ir}(\mathrm{III})$ chloro-bridged dimers, $\left[(\mathrm{pbo})_{2} \operatorname{Ir}(\mu-\mathrm{Cl})_{2} \operatorname{Ir}(\mathrm{pbo})_{2}\right]$ (D1), and $\left[(\mathrm{dfpbo})_{2} \operatorname{Ir}(\mu-\mathrm{Cl})_{2} \operatorname{Ir}(\mathrm{dfpbo})_{2}\right](\mathrm{D} 2)$ were synthesized by the method shown in our previous reports.

\subsubsection{Synthesis of Cyclometalated $\operatorname{Ir}(\mathrm{III})$ Chloro-Bridged Dimer $\left.\left[(\mathrm{dfpbo})_{2} \operatorname{Ir}(\mu-\mathrm{I})_{2}\right) \operatorname{Ir}(\mathrm{dfpbo})_{2}\right](\mathrm{D} 3)$}

A cyclometalated Ir(III) Iodo-bridged dimer, D3, was synthesized according to the Finkelstein method. A flask was charged with $2 \mathrm{~g}$ ( $1.6 \mathrm{mmole})$ of dimer D2 and $2.18 \mathrm{~g}$ ( 24 mmole) of sodium iodide, and $100 \mathrm{~mL}$ of acetone was added. The solution was stirred and warmed to $100{ }^{\circ} \mathrm{C}$ for $24 \mathrm{~h}$ under nitrogen. After cooling to room temperature, the mixture was poured into $500 \mathrm{~mL}$ of pure water. The precipitate of cyclometalated iridium dimer was collected, washed with deionized water, and dried at $60^{\circ} \mathrm{C}$ in a vacuum oven. The product was used as a precursor for complexes 7-9 without further purifying. The yield of dimer D3 was $1.5568 \mathrm{~g}(62 \%)$ of a yellow solid. ${ }^{1} \mathrm{H}$ NMR $(300 \mathrm{MHz}$, $\left.\mathrm{CDCl}_{3}, 298 \mathrm{~K} ; \delta(\mathrm{ppm})\right)$ : 9.07-9.10 (m, 2H), 7.99-8.77 (m, 2H), 7.92-7.99 (m, 4H), 7.55-7.65 (m, 12H), 
6.72-6.83 (m, 4H). Anal. Calcd for $\mathrm{C}_{52} \mathrm{H}_{24} \mathrm{~N}_{4} \mathrm{I}_{2} \mathrm{O}_{4} \mathrm{~F}_{8} \mathrm{Ir}_{2}\left(M_{\mathrm{W}}=1559.60\right)$ : $\mathrm{C}, 40.01 ; \mathrm{H}, 1.53 ; \mathrm{N}, 3.59$. Found: C, 40.36; H, 1.64; N, 3.67. MS (FAB; $m / z)$ : 1559.6098 .

3.2.3. Synthesis of Bis(2-phenylbenzoxazolato- $\left.\mathrm{N}, \mathrm{C}^{2}\right)$-pyridinato Chloroiridium(III) $\left[\operatorname{Ir}(\mathrm{pbo})_{2}(\mathrm{Cl})(\mathrm{py})\right](\mathbf{1})$

A flask was charged with $0.5 \mathrm{~g}(0.41 \mathrm{mmol})$ of D1, $0.48 \mathrm{~g}(0.61 \mathrm{mmol})$ of pyridine, and $30 \mathrm{~mL}$ of toluene. The solution was stirred under $\mathrm{N}_{2}$ and warmed to $130^{\circ} \mathrm{C}$. After $1 \mathrm{~h}$, the solution was cooled to room temperature; the reaction mixture was purified by column chromatography on silica gel with dichloromethane/n-hexane as the eluent. The yield of complex 1 was $0.4438 \mathrm{~g}(80 \%)$ of yellow crystals. ${ }^{1} \mathrm{H} \mathrm{NMR}\left(300 \mathrm{MHz}, \mathrm{CDCl}_{3}, 298 \mathrm{~K} ; \delta(\mathrm{ppm})\right): 8.96(\mathrm{~d}, J=4.8 \mathrm{~Hz}, 2 \mathrm{H}), 8.76(\mathrm{~d}, J=8.1 \mathrm{~Hz}, 1 \mathrm{H}), 7.66-7.72$ $(\mathrm{m}, 3 \mathrm{H}), 7.29-7.45(\mathrm{~m}, 3 \mathrm{H}), 7.13-7.20(\mathrm{~m}, 5 \mathrm{H}), 6.97(\mathrm{t}, J=7.5,7.5 \mathrm{~Hz} 1 \mathrm{H}), 6.78-6.84(\mathrm{~m}, 3 \mathrm{H}), 6.49-6.51$ (m, 2H), 5.26-5.28 (m, 1H). ${ }^{13} \mathrm{C}$ NMR (75 MHz, $\mathrm{CDCl}_{3}, 298 \mathrm{~K} ; \delta$ (ppm)): 179.4, 176.3, 154.3, 152.9, 152.8, 151.0, 150.2, 145.8, 140.2, 138.5, 138.0, 137.8, 137.1, 137.0, 135.0, 134.9, 132.9, 131.8, 131.6, 129.2, 126.1, 125.9, 125.8, 125.2, 125.0, 121.8, 121.6, 116.7, 114.5, 111.9, 104.8. Anal. Calcd for $\mathrm{C}_{31} \mathrm{H}_{21} \mathrm{~N}_{3} \mathrm{O}_{2} \mathrm{ClIr}$ $\left(M_{W}=695.10\right): C, 53.51 ; H, 3.02 ; N, 6.04$. Found: $C, 53.62 ; H, 2.94 ; N, 5.96$. MS (FAB; $\left.m / z\right): 694.0955$.

3.2.4. Synthesis of Bis(2-phenylbenzoxazolato- $\left.\mathrm{N}, \mathrm{C}^{2^{\prime}}\right)$-(4-methylpyridinato) Chloroiridium(III) $\left[\operatorname{Ir}(\mathrm{pbo})_{2}(\mathrm{Cl})(4 \mathrm{mpy})\right](2)$

A flask was charged with $0.5 \mathrm{~g}(0.41 \mathrm{mmol})$ of D1, $0.571 \mathrm{~g}(6.15 \mathrm{mmol})$ of methylpyridine, and $30 \mathrm{~mL}$ of toluene. The solution was stirred under $\mathrm{N}_{2}$ and warmed to $130^{\circ} \mathrm{C}$. After $2.5 \mathrm{~h}$, the solution was cooled to room temperature; the reaction mixture was purified by column chromatography on silica gel with dichloromethane/n-hexane as the eluent. The yield of complex 2 was $0.4075 \mathrm{~g}(70 \%)$ of yellow crystals. ${ }^{1} \mathrm{H}$ NMR $\left(300 \mathrm{MHz}, \mathrm{CDCl}_{3}, 298 \mathrm{~K} ; \delta(\mathrm{ppm})\right): 8.77(\mathrm{~d}, J=5.1 \mathrm{~Hz}, 2 \mathrm{H}), 8.56(\mathrm{~d}, J=7.8 \mathrm{~Hz}$, $1 \mathrm{H}), 7.66-7.73(\mathrm{~m}, 3 \mathrm{H}), 7.23-7.45(\mathrm{~m}, 4 \mathrm{H}), 7.12-7.17(\mathrm{~m}, 3 \mathrm{H}), 6.97-7.12(\mathrm{~m}, 3 \mathrm{H}), 6.88-6.94(\mathrm{~m}, 1 \mathrm{H})$, 6.77-6.82 (m, 2H), 6.43-6.51 (m, 1H), 2.28 (s, 3H). ${ }^{13} \mathrm{C} \mathrm{NMR} \mathrm{(75} \mathrm{MHz,} \mathrm{CDCl} 3,298 \mathrm{~K} ; \delta$ (ppm)): 179.7, 176.6, 154.9, 152.5, 151.3, 150.5, 149.1, 146.7, 140.6, 138.9, 135.3, 133.1, 132.2, 131.9, 129.5, 126.3, 125.2, 122.0, 121.9, 117.2, 112.3, 53.9, 21.5. Anal. Calcd for $\mathrm{C}_{32} \mathrm{H}_{23} \mathrm{~N}_{3} \mathrm{O}_{2} \mathrm{ClIr}\left(\mathrm{M}_{\mathrm{W}}=709.11\right): \mathrm{C}, 54.20 ; \mathrm{H}, 3.27$; $\mathrm{N}$, 5.93. Found: $\mathrm{C}, 53.95 ; \mathrm{H}, 3.28 ; \mathrm{N}, 5.76$. MS (FAB; $m / z)$ : 708.11.

3.2.5. Synthesis of Bis(2-phenylbenzoxazolato- $\left.\mathrm{N}, \mathrm{C}^{2}\right)$-(4-cyanopyridinato) Chloroiridium(III) $\left[\operatorname{Ir}(\mathrm{pbo})_{2}(\mathrm{Cl})(4 \mathrm{cnpy})\right](3)$

A flask was charged with $0.5 \mathrm{~g}(0.41 \mathrm{mmol})$ of D1, $0.638 \mathrm{~g}(6.15 \mathrm{mmol})$ of 4-cyanopyridine, and $30 \mathrm{~mL}$ of toluene. The solution was stirred under $\mathrm{N}_{2}$ and warmed to $130^{\circ} \mathrm{C}$. After $3 \mathrm{~h}$, the solution was cooled to room temperature; the reaction mixture was purified by column chromatography on silica gel with dichloromethane/n-hexane as the eluent. The yield of complex 3 was $0.4596 \mathrm{~g}(78 \%)$ of orange crystals. ${ }^{1} \mathrm{H}$ NMR $\left(300 \mathrm{MHz}, \mathrm{CDCl}_{3}, 298 \mathrm{~K} ; \delta(\mathrm{ppm})\right): 9.20(\mathrm{~d}, J=5.4 \mathrm{~Hz}, 2 \mathrm{H}), 8.48(\mathrm{~d}, J=7.8 \mathrm{~Hz}$, $1 \mathrm{H}), 7.67-7.7(\mathrm{~m}, 3 \mathrm{H}), 7.41-7.49(\mathrm{~m}, 4 \mathrm{H}), 7.27-7.36(\mathrm{~m}, 3 \mathrm{H}), 7.15-7.21(\mathrm{~m}, 1 \mathrm{H}), 7.00(\mathrm{t}, J=7.8,8.1 \mathrm{~Hz}$, 1H), 6.77-6.83 (m, 3H), 6.40-6.46 (m, 2H). ${ }^{13} \mathrm{C}$ NMR (75 MHz, $\left.\mathrm{CDCl}_{3}, 298 \mathrm{~K} ; \delta(\mathrm{ppm})\right): 179.3,176.1$, 154.1, 153.1, 151.0, 150.2, 144.1, 140.1, 138.3, 137.7, 134.7, 131.9, 131.5, 129.1, 127.0, 126.8, 126.1, 125.3, 122.3, 121.0, 116.2, 115.9, 112.3. Anal. Calcd for $\mathrm{C}_{32} \mathrm{H}_{20} \mathrm{~N}_{4} \mathrm{O}_{2} \mathrm{ClIr}\left(M_{\mathrm{W}}=720.09\right): \mathrm{C}, 53.27 ; \mathrm{H}, 2.80 ; \mathrm{N}$, 7.78. Found: C, 53.19; H, 2.70; N, 7.76. MS (FAB; $m / z): 719.0903$.

3.2.6. Synthesis of Bis(2-(3,5-difluorophenyl)benzoxazolato- $\left.\mathrm{N}, \mathrm{C}^{2}\right)$-pyridinato Chloroiridium(III) $\left[\operatorname{Ir}(\mathrm{dfpbo})_{2}(\mathrm{Cl})(\mathrm{py})\right](4)$

A flask was charged with $0.5 \mathrm{~g}(0.36 \mathrm{mmol})$ of $\mathbf{D} 2,0.38 \mathrm{~g}(5.45 \mathrm{mmol})$ of pyridine, and $30 \mathrm{~mL}$ of toluene. The solution was stirred under $\mathrm{N}_{2}$ and warmed to $130^{\circ} \mathrm{C}$. After $2.5 \mathrm{~h}$, the solution was cooled to room temperature; the reaction mixture was purified by column chromatography on silica gel with dichloromethane/n-hexane as the eluent. The yield of complex 4 was $0.4064 \mathrm{~g}(74 \%)$ of yellow crystals. ${ }^{1} \mathrm{H}$ NMR $\left(300 \mathrm{MHz}, \mathrm{CDCl}_{3}, 298 \mathrm{~K} ; \delta(\mathrm{ppm})\right)$ : 9.11-9.14 (m, 1H), 7.75-7.81 (m, 1H), 7.54-7.64 (m, 2H), 7.41-7.48 (m, 2H), 7.26-7.38 (m, 7H), $7.08(\mathrm{t}, J=8.1,7.8 \mathrm{~Hz} 1 \mathrm{H}), 6.35-6.42(\mathrm{~m}, 1 \mathrm{H}), 6.25-6.32(\mathrm{~m}, 1 \mathrm{H}), 6.18$ 
$(\mathrm{d}, J=8.1 \mathrm{~Hz}, 1 \mathrm{H}) .{ }^{13} \mathrm{C} \mathrm{NMR}\left(75 \mathrm{MHz}, \mathrm{CDCl}_{3}, 298 \mathrm{~K} ; \delta(\mathrm{ppm})\right): 167.1,157.9,150.1,149.7,140.9,138.8$, 137.7, 137.6, 133.3, 133.1, 132.9, 125.7, 122.3, 116.9, 112.2, 108.8, 53.5. Anal. Calcd for $\mathrm{C}_{31} \mathrm{H}_{17} \mathrm{~N}_{3} \mathrm{O}_{2} \mathrm{ClF}_{4} \mathrm{Ir}$ $\left(M_{\mathrm{W}}=767.06\right): \mathrm{C}, 48.49 ; \mathrm{H}, 2.36 ; \mathrm{N}$, 5.47. Found: $\mathrm{C}, 47.96 ; \mathrm{H}, 2.43 ; \mathrm{N}, 5.43$. MS (FAB; $\left.m / z\right): 767.0576$.

3.2.7. Synthesis of Bis(2-(3,5-difluorophenyl)benzoxazolato-N, $\left.\mathrm{C}^{2}\right)$-(4-methylpyridinato) Chloroiridium(III) $\left[\mathrm{Ir}(\mathrm{dfpbo})_{2}(\mathrm{Cl})(4 \mathrm{mpy})\right]$ (5)

A flask was charged with $0.5 \mathrm{~g}(0.36 \mathrm{mmol})$ of D2, $0.5076 \mathrm{~g}(5.4 \mathrm{mmol})$ of methylpyridine, and $30 \mathrm{~mL}$ of toluene. The solution was stirred under $\mathrm{N}_{2}$ and warmed to $130^{\circ} \mathrm{C}$. After $1 \mathrm{~h}$, the solution was cooled to room temperature; the reaction mixture was purified by column chromatography on silica gel with dichloromethane/n-hexane as the eluent. The yield of complex 5 was $0.3980 \mathrm{~g}(71 \%)$ of orange crystals. ${ }^{1} \mathrm{H}$ NMR $\left(300 \mathrm{MHz}, \mathrm{CDCl}_{3}, 298 \mathrm{~K} ; \delta(\mathrm{ppm})\right)$ : 9.10-9.13 $(\mathrm{m}, 1 \mathrm{H}), 7.54-7.63(\mathrm{~m}, 2 \mathrm{H})$, 7.38-7.47 (m, 2H), 7.23-7.35 (m, 5H), 7.05-7.13 (m, 3H), 6.24-6.40 (m, 3H), 2.34 (s, 3H). ${ }^{13} \mathrm{C}$ NMR $\left(75 \mathrm{MHz}, \mathrm{CDCl}_{3}, 298 \mathrm{~K} ; \delta\right.$ (ppm)): 176.3, 170.6, 170.0, 167.5, 166.9, 161.2, 158.0, 153.5, 150.2, 150.1, 150.0, 140.5, 139.1, 133.9, 133.8, 133.6, 133.5, 126.5, 125.8, 122.7, 121.6, 120.4, 119.8, 119.3, 116.7, 116.4, 112.2, 111.3, 109.5, 109.0, 108.7, 107.9. Anal. Calcd for $\mathrm{C}_{32} \mathrm{H}_{19} \mathrm{ClF}_{4} \operatorname{IrN}_{3} \mathrm{O}_{2}\left(\mathrm{M}_{\mathrm{W}}=781.18\right): \mathrm{C}, 49.15 ; \mathrm{H}, 2.58 ; \mathrm{N}$, 5.37. Found: $\mathrm{C}, 49.15 ; \mathrm{H}, 2.58 ; \mathrm{N}, 5.37$. MS (FAB; $m / z)$ : 781.0732 .

3.2.8. Synthesis of Bis(2-(3,5-difluorophenyl)benzoxazolato-N, $\left.\mathrm{C}^{2}\right)$-(4-cyanopyridinato) Chloroiridium(III) $\left[\mathrm{Ir}(\mathrm{dfpbo})_{2}(\mathrm{Cl})(4 \mathrm{cnpy})\right](6)$

A flask was charged with $0.5 \mathrm{~g}(0.36 \mathrm{mmol})$ of D2, $0.5674 \mathrm{~g}(5.4 \mathrm{mmol})$ of 4-cyanopyridine, and $30 \mathrm{~mL}$ of toluene. The solution was stirred under $\mathrm{N}_{2}$ and warmed to $130^{\circ} \mathrm{C}$. After $1 \mathrm{~h}$, the solution was cooled to room temperature; the reaction mixture was purified by column chromatography on silica gel with dichloromethane/n-hexane as the eluent. The yield of complex 6 was $0.4893 \mathrm{~g}(86 \%)$ of yellow crystals. ${ }^{1} \mathrm{H}$ NMR $\left(300 \mathrm{MHz}, \mathrm{CDCl}_{3}, 298 \mathrm{~K} ; \delta(\mathrm{ppm})\right)$ : $9.03-9.07(\mathrm{~m}, 2 \mathrm{H}), 7.66(\mathrm{~d}, J=8.4 \mathrm{~Hz}, 1 \mathrm{H})$, 7.58-7.62 (m, H), 7.43-7.56 (m, 4H), 7.28-7.42 (m, 3H), 7.12-7.18(m, 2H), 6.38-6.45 (m, H), 6.26-6.33 $(\mathrm{m}, \mathrm{H}), 6.16(\mathrm{~d}, J=8.4 \mathrm{~Hz}, \mathrm{H}) .{ }^{13} \mathrm{C}$ NMR $\left(75 \mathrm{MHz}, \mathrm{CDCl}_{3}, 298 \mathrm{~K} ; \delta(\mathrm{ppm})\right): 155.4,150.1,140.1,138.9$, 127.2, 126.6, 125.8, 122.1, 120.1, 115.4, 112.5, 111.4, 109.6, 104.9. Anal. Calcd for $\mathrm{C}_{32} \mathrm{H}_{16} \mathrm{~N}_{4} \mathrm{O}_{2} \mathrm{ClF}_{4} \mathrm{Ir}$ $\left(M_{\mathrm{W}}=791.16\right)$ : C, 48.52; H, 2.39; N, 7.07. Found: C, 48.27; H, 2.50; N, 6.90. MS (FAB; $\left.m / z\right)$ : 791.0609.

3.2.9. Synthesis of Bis(2-(3,5-difluorophenyl)benzoxazolato- $\left.N, \mathrm{C}^{2^{\prime}}\right)$-pyridinato Iodoiridium(III) $\left[\operatorname{Ir}(\mathrm{dfpbo})_{2}(\mathrm{I})(\mathrm{py})\right](7)$

A flask was charged with $0.15 \mathrm{~g}(0.096 \mathrm{mmol})$ of D3, $0.11 \mathrm{~g}(1.44 \mathrm{mmol})$ of pyridine, and $30 \mathrm{~mL}$ of toluene. The solution was stirred under $\mathrm{N}_{2}$ and warmed to $130^{\circ} \mathrm{C}$. After $3.5 \mathrm{~h}$, the solution was cooled to room temperature; the reaction mixture was purified by column chromatography on silica gel with dichloromethane/n-hexane as the eluent. The yield of complex 7 was $0.1404 \mathrm{~g}(85 \%)$ of yellow crystals. ${ }^{1} \mathrm{H}$ NMR $\left(300 \mathrm{MHz}, \mathrm{CDCl}_{3}, 298 \mathrm{~K} ; \delta(\mathrm{ppm})\right): 9.55(\mathrm{~d}, J=9.55 \mathrm{~Hz}, \mathrm{H}), 7.75(\mathrm{t}, J=7.8,8.1 \mathrm{~Hz}, \mathrm{H}), 7.64(\mathrm{~d}$, $J=8.4 \mathrm{~Hz}, \mathrm{H}), 7.47-7.59(\mathrm{~m}, 3 \mathrm{H}), 7.33-7.44(\mathrm{~m}, 2 \mathrm{H}), 7.12-7.24(\mathrm{~m}, 6 \mathrm{H}), 6.49(\mathrm{~d}, J=8.4 \mathrm{~Hz}, \mathrm{H}), 6.28-6.41$ (m, 2H). ${ }^{13} \mathrm{C}$ NMR $\left(75 \mathrm{MHz}, \mathrm{CDCl}_{3}, 298 \mathrm{~K} ; \delta\right.$ (ppm)): 157.9, 150.1, 149.7, 140.9, 138.8, 137.7, 137.6, 133.3, 133.1, 132.9, 125.7, 124.4, 122.3, 118.9, 116.9, 112.1, 108.8, 107.3. Anal. Calcd for $\mathrm{C}_{31} \mathrm{H}_{17} \mathrm{~N}_{3} \mathrm{O}_{2} \mathrm{IF}_{4} \mathrm{Ir}$ $\left(M_{\mathrm{W}}=859.99\right): \mathrm{C}, 43.30 ; \mathrm{H}, 1.97 ; \mathrm{N}, 4.88$. Found: $\mathrm{C}, 43.53 ; \mathrm{H}, 2.09 ; \mathrm{N}, 4.59$. MS (FAB; $\left.m / z\right): 859.0011$.

3.2.10. Synthesis of Bis(2-(3,5-difluorophenyl)benzoxazolato- $\left.\mathrm{N}, \mathrm{C}^{2}\right)$-(4-methylpyridinato) Iodoiridium(III) $\left[\mathrm{Ir}(\mathrm{dfpbo})_{2}(\mathrm{I})(4 \mathrm{mpy})\right](8)$

A flask was charged with $0.3 \mathrm{~g}(0.19 \mathrm{mmol})$ of D3, $0.27 \mathrm{~g}(2.87 \mathrm{mmol})$ of 4-methylpyridine, and $40 \mathrm{~mL}$ of toluene. The solution was stirred under $\mathrm{N}_{2}$ and warmed to $130^{\circ} \mathrm{C}$. After $4 \mathrm{~h}$, the solution was cooled to room temperature; the reaction mixture was purified by column chromatography on silica gel with dichloromethane/n-hexane as the eluent. The yield of complex 8 was $0.2871 \mathrm{~g}(87 \%)$ of yellow crystals. ${ }^{1} \mathrm{H}$ NMR $\left(300 \mathrm{MHz}, \mathrm{CDCl}_{3}, 298 \mathrm{~K} ; \delta(\mathrm{ppm})\right): 9.53-9.55(\mathrm{~m}, 1 \mathrm{H}), 7.26-7.65(\mathrm{~m}, 7 \mathrm{H})$, 7.14-7.24 (m, 3H), $7.14(\mathrm{~S}, 2 \mathrm{H}), 6.59-7.00(\mathrm{~m}, 1 \mathrm{H}), 6.27-6.57(\mathrm{~m}, 2 \mathrm{H}) 2.32(\mathrm{~S}, 3 \mathrm{H}) .{ }^{13} \mathrm{C} \mathrm{NMR}(75 \mathrm{MHz}$, $\left.\mathrm{CDCl}_{3}, 298 \mathrm{~K} ; \delta(\mathrm{ppm})\right): 176.8,175.5,170.4,169.3,167.0,166.0,161.1,157.9,156.2,150.1,149.6,140.9$, 
138.9, 133.0, 126.3, 126.0, 125.8, 124.0, 123.4, 122.3, 119.5, 119.0, 116.9, 111.9, 111.2, 109.3, 108.7, 108.5, 21.1. Anal. Calcd for $\mathrm{C}_{32} \mathrm{H}_{19} \mathrm{~N}_{3} \mathrm{O}_{2} \mathrm{IF}_{4} \operatorname{Ir}\left(M_{\mathrm{W}}=873.01\right)$ : $\mathrm{C}, 43.98 ; \mathrm{H}, 2.17 ; \mathrm{N}, 5.04$. Found: $\mathrm{C}, 43.92 ; \mathrm{H}$, 2.33; N, 4.91. MS (FAB; $m / z)$ : 873.0170.

3.2.11. Synthesis of Bis(2-(3,5-difluorophenyl)benzoxazolato-N, $\left.\mathrm{C}^{2}\right)$-(4-cyanopyridinato) Iodoiridium(III) $\left[\operatorname{Ir}(\mathrm{dfpbo})_{2}(\mathrm{I})(4 \mathrm{cnpy})\right](9)$

A flask was charged with $0.3 \mathrm{~g}(0.19 \mathrm{mmol})$ of $\mathrm{D} 3,0.3 \mathrm{~g}(2.87 \mathrm{mmol})$ of 4-cyanopyridine, and $40 \mathrm{~mL}$ of toluene. The solution was stirred under $\mathrm{N}_{2}$ and warmed to $130{ }^{\circ} \mathrm{C}$. After $3 \mathrm{~h}$, the solution was cooled to room temperature; the reaction mixture was purified by column chromatography on silica gel with dichloromethane/n-hexane as the eluent. The yield of complex 9 was $0.2341 \mathrm{~g}(70 \%)$ of yellow crystals. ${ }^{1} \mathrm{H}$ NMR $\left(300 \mathrm{MHz}, \mathrm{CDCl}_{3}, 298 \mathrm{~K} ; \delta(\mathrm{ppm})\right): 9.51(\mathrm{~d}, J=8.1 \mathrm{~Hz}, 1 \mathrm{H}), 7.67(\mathrm{~d}, J=8.4 \mathrm{~Hz}, 1 \mathrm{H})$, 7.40-7.61 (m, 6H), 7.33-7.36 (m, 1H), 7.18-7.21 (m, 4H), 6.28-6.48 (m, 3H). ${ }^{13} \mathrm{C}$ NMR $\left(75 \mathrm{MHz}, \mathrm{CDCl}_{3}\right.$ ， $298 \mathrm{~K} ; \delta(\mathrm{ppm})): 176.9,175.2,170.1,169.2,166.9,166.0,161.3,158.0,150.1,149.7,140.6,138.7,132.9$, 127.3, 126.4, 125.9, 125.7, 123.3, 122.8, 122.0, 121.8, 116.9, 116.2, 1125, 111.6, 109.4, 108.9, 53.5. Anal. Calcd for $\mathrm{C}_{32} \mathrm{H}_{16} \mathrm{~N}_{4} \mathrm{O}_{2} \mathrm{IF}_{4} \mathrm{Ir}\left(\mathrm{M}_{\mathrm{W}}=883.61\right)$ : C, 43.45; H, 1.81; N, 6.33. Found: $\mathrm{C}, 42.39 ; \mathrm{H}, 2.03 ; \mathrm{N}, 5.77$. MS (FAB; $m / z): 883.9958$.

\subsection{X-ray Absorption Near-Edge Spectroscopy (XANES)}

XANES was measured on equipment from the National Synchrotron Radiation Research Center (NSRRC, Hsinchu, Taiwan). A Si (111) double crystal monochromator was employed for energy scanning (Horiba, Kyoto, Japan). Fluorescence data were obtained at room temperature using an Ar-filled ionization chamber detector, where each sample was scanned three times for averaging.

\subsection{Thermogravimetric Analysis (TGA)}

The experiments were performed with a Perkin-Elmer thermal gravimetric analyzer (Perkin-Elmer, Waltham, MA, USA). The samples were heated up under nitrogen at a pressure of $1 \mathrm{~atm}$ with a heating rate of $10{ }^{\circ} \mathrm{C} \mathrm{min}^{-1}$ and finished at $670{ }^{\circ} \mathrm{C}$.

\subsection{Electron Paramagnetic Resonance (EPR)}

EPR was measured with a Bruker EMX-10/12 spectrometer (Bruker, Billerica, MA, USA). The samples were dissolved in toluene. EPR settings: field, center field $3520.000 \mathrm{G}$, sweep width $100.000 \mathrm{G}$, resolution 2048 points; microwave frequency, $9.879 \mathrm{GHz}$; microwave power, $10.080 \mathrm{~mW}$; number of scans, 1 .

\subsection{Single Crystal X-ray Diffraction}

All of the crystals were obtained from a mixed solution of dichloromethane and n-hexane. The diffraction data for complexes 1-3 were collected on a Bruker SMART APEX CCD diffractometer (Bruker, Billerica, MA, USA) with a graphite-monochromatized Mo K $\alpha$ X-ray radiation $(\lambda=0.71073 \AA)$ at $110 \mathrm{~K}$. All of the calculations for the structural determination were carried out using a SHELXS-97 package (Bruker). The positions of the heavy atoms, including the iridium atoms, were located by the direct method. The remaining atoms were found in a series of alternating difference Fourier maps and least-square refinement. The crystallographic data for all of the structures reported here have been deposited in the Cambridge Data Centre as supplementary publication numbers 953386, 953387, 1511643, and 1511645-1511648, respectively.

\subsection{Catalytic Activity of Catalysts}

The reaction temperature was well controlled in a silicon oil bath under a constant temperature $\left( \pm 1{ }^{\circ} \mathrm{C}\right)$. To evaluate the catalytic activity of complexes $\mathbf{1 - 9}$, the oxidation of toluene was done by the following procedure. A flask was charged with $5 \mathrm{~mL}$ of toluene containing complexes 1-9 with 
various concentrations between $1 \times 10^{-6}$ and $1 \times 10^{-2} \mathrm{M}$. The reaction temperature was gradually increased to $100{ }^{\circ} \mathrm{C}$ and kept constant during the oxidation experiments. During the reactions, the concentrations of the reactant and product were monitored with an instrument of high performance liquid chromatography (HPLC).

\section{Conclusions}

A series of cyclometalated iridium(III) complexes composed of various cyclometalating ligands were synthesized and fully characterized. These complexes are quite stable, and can be stored in air at room temperature for a year without obvious decomposition. All of the complexes exhibited activity for the catalytic oxidation of toluene with a green process for the production of benzaldehyde without requiring a base, halogen, or other environmentally-unfriendly materials [41-44].

A plausible catalytic cycle is proposed for this kind of reaction. The coordinatively unsaturated structure $\left[\left(\mathrm{C}^{\wedge} \mathrm{N}\right)_{2} \operatorname{Ir}(\mathrm{Cl})\right]$ with a vacant site is an important structure for the catalytic system, and the catalytic ability of the complexes are mainly governed by the characteristics of the $\mathrm{C}^{\wedge} \mathrm{N}$ ligand. By using these complexes for the catalytic oxidation of benzyl alcohol, the maximum catalytic rate can reach $20.3 \mu \mathrm{M} \mathrm{s}^{-1}$, and the catalytic frequency can be up to $9940 \mathrm{~h}^{-1}$. The chemoselectivity for the catalytic oxidation of benzyl alcohol to benzaldehyde is quite high (up to 97\%), which is obviously affected by the structure of bidentate cyclometalating ligands $\left(\mathrm{C}^{\wedge} \mathrm{N}\right)$.

Supplementary Materials: The following are available online at http:/ /www.mdpi.com/2304-6740/6/4/118/s1, Basic information pertaining to the crystal parameters and structure refinement, and calculation detail (PDF), Crystallographic data for 1, 2, 4-6, 8, 9 (TXT). Figures S1-S3: NMR, IR, MS spectra of D2 and that of the precipitate formed in reaction, Figures S4 and S5: Calibration curve for benzaldehyde and benzoic acid, Tables S1-S3: Crystal data for complexes 1, 2, 4-6, 8, 9, Table S4: Reaction rate $(\mu \mathrm{M} / \mathrm{s})$ of the catalytic oxidation for toluene, Table S5: Rate constants and activation energy of the catalytic oxidation for toluene, Table S6: Reaction rates, catalytic frequencies, concentration of the product and turnover number of catalytic oxidation of toluene with various concentrations of complexes as catalysts.

Author Contributions: Conceptualization, T.-R.C.; Methodology, P.C.L. and T.-R.C.; Software, P.C.L.; Formal Analysis, P.C.L.; Investigation, P.C.L.; Resources, K.H.-C.C.; Data Curation, P.C.L.; Writing-Original Draft Preparation, P.C.L.; Writing-Review \& Editing, T.-R.C. and J.-D.C.; Project Administration, T.-R.C.

Funding: This work was supported by Ministry of Science and Technology (Grant No. MOST 103-2113-M-153-001).

Acknowledgments: We are grateful to Jyh-Fu Lee from National Synchrotron Radiation Research Center (NSRRC) for the X-ray absorption measurements.

Conflicts of Interest: The authors declare no conflict of interest.

\section{References}

1. Chen, G.-J.; Wang, J.-S.; Jin, F.-Z.; Liu, M.-Y.; Zhao, C.-W.; Li, Y.-A.; Dong, Y.-B. Pd@Cu(II)-MOF-Catalyzed Aerobic Oxidation of Benzylic Alcohols in Air with High Conversion and Selectivity. Inorg. Chem. 2016, 55, 3058-3064. [CrossRef] [PubMed]

2. Backvall, J.E. Modern Oxidation Reactions, 1st ed.; Wiley-VCH: Weinheim, Germany, 2004.

3. Fernandez, M.I.; Tojo, G. Oxidation of Alcohols to Aldehydes and Ketones. In A Guide to Current Common Practice; Springer: New York, NY, USA, 2006.

4. Long, R.; Huang, H.; Li, Y.P.; Song, L.; Xiong, Y. Palladium-Based Nanomaterials: A Platform to Produce Reactive Oxygen Species for Catalyzing Oxidation Reactions. Adv. Mater. 2015, 27, 7025-7042. [CrossRef] [PubMed]

5. Chen, T.-R.; Lee, H.-P.; Chen, J.-D.; Chen, K.H.-C. An $18+\delta$ iridium dimer releasing metalloradicals spontaneously. Dalton Trans. 2010, 39, 9458-9461. [CrossRef] [PubMed]

6. Chen, T.-R.; Liu, P.-C.; Lee, H.-P.; Wu, F.-S.; Chen, K.H.-C. Cyclometalated Iridium(III) Complexes with Ligand Effects on the Catalytic C-H Bond Activation of Toluene. Eur. J. Inorg. Chem. 2017, 13, 2023-2031. [CrossRef] 
7. Al-Rifai, N.; Miedziak, P.J.; Morad, M.; Sankar, M.; Waldron, C.; Cattaneo, S.; Cao, E.; Pattisson, S.; Morgan, D.; Bethell, D.; et al. Deactivation Behavior of Supported Gold Palladium Nanoalloy Catalysts during the Selective Oxidation of Benzyl Alcohol in a Micropacked Bed Reactor. Ind. Eng. Chem. Res. 2017, 56, 12984-12993. [CrossRef]

8. Jiang, N.; Ragauskas, A.J. Cu(II)-Catalyzed Selective Aerobic Oxidation of Alcohols under Mild Conditions. J. Org. Chem. 2006, 71, 7087-7090. [CrossRef] [PubMed]

9. Huang, W.; Ma, B.C.; Lu, H.; Li, R.; Wang, L.; Landfester, K.; Zhang, K.A.I. Visible-Light-Promoted Selective Oxidation of Alcohols Using a Covalent Triazine Framework. ACS Catal. 2017, 7, 5438-5442. [CrossRef]

10. Graves, C.R.; Zeng, B.-S.; Nguyen, S.T. Efficient and Selective Al-Catalyzed Alcohol Oxidation via Oppenauer Chemistry. J. Am. Chem. Soc. 2006, 128, 12596-12597. [CrossRef] [PubMed]

11. Su, F.; Mathew, S.C.; Lipner, G.; Fu, X.; Antonietti, M.; Blechert, S.; Wang, X. mpg- $\mathrm{C}_{3} \mathrm{~N}_{4}$-Catalyzed Selective Oxidation of Alcohols Using $\mathrm{O}_{2}$ and Visible Light. J. Am. Chem. Soc. 2010, 132, 16299-16301. [CrossRef] [PubMed]

12. Li, H.; Qin, F.; Yang, Z.; Cui, X.; Wang, J.; Zhang, L. New Reaction Pathway Induced by Plasmon for Selective Benzyl Alcohol Oxidation on BiOCl Possessing Oxygen Vacancies. J. Am. Chem. Soc. 2017, 139, 3513-3521. [CrossRef] [PubMed]

13. Khenkin, A.M.; Neumann, R. Oxygen Transfer from Sulfoxides: Selective Oxidation of Alcohols Catalyzed by Polyoxomolybdates. J. Org. Chem. 2002, 67, 7075-7079. [CrossRef] [PubMed]

14. Shaikh, T.M.A.; Emmanuvel, L.; Sudalai, A. NaIO 4 -Mediated Selective Oxidation of Alkylarenes and Benzylic Bromides/Alcohols to Carbonyl Derivatives Using Water as Solvent. J. Org. Chem. 2006, 71, 5043-5046. [CrossRef] [PubMed]

15. Chorghade, R.; Battilocchio, C.; Hawkins, J.M.; Ley, S.V. Sustainable Flow Oppenauer Oxidation of Secondary Benzylic Alcohols with a Heterogeneous Zirconia Catalyst. Org. Lett. 2013, 15, 5698-5701. [CrossRef] [PubMed]

16. Verma, S.; Baig, R.B.N.; Nadagouda, M.N.; Varma, R.S. Selective Oxidation of Alcohols Using Photoactive VO@g-C $\mathrm{C}_{3}$. ACS Sustain. Chem. Eng. 2016, 4, 1094-1098. [CrossRef]

17. Peterson, K.P.; Larock, R.C. Palladium-Catalyzed Oxidation of Primary and Secondary Allylic and Benzylic Alcohols. J. Org. Chem. 1998, 63, 3185-3189. [CrossRef]

18. Sharma, M.; Das, B.; Sharma, M.; Deka, B.K.; Park, Y.-B.; Bhargava, S.K.; Bania, K.K. Pd/Cu-Oxide Nanoconjugate at Zeolite-Y Crystallite Crafting the Mesoporous Channels for Selective Oxidation of Benzyl-Alcohols. ACS Appl. Mater. Interfaces 2017, 9, 35453-35462. [CrossRef] [PubMed]

19. Moriyama, K.; Takemura, M.; Togo, H. Direct and Selective Benzylic Oxidation of Alkylarenes via C-H Abstraction Using Alkali Metal Bromides. Org. Lett. 2012, 14, 2414-2417. [CrossRef] [PubMed]

20. Hanson, S.K.; Wu, R.; Silks, L.P. Mild and Selective Vanadium-Catalyzed Oxidation of Benzylic, Allylic, and Propargylic Alcohols Using Air. Org. Lett. 2011, 13, 1908-1911. [CrossRef] [PubMed]

21. Long, J.; Xie, X.; Xu, J.; Gu, Q.; Chen, L.; Wang, X. Nitrogen-Doped Graphene Nanosheets as Metal-Free Catalysts for Aerobic Selective Oxidation of Benzylic Alcohols. ACS Catal. 2012, 2, 622-631. [CrossRef]

22. Xu, J.; Luo, L.; Xiao, G.; Zhang, Z.; Lin, H.; Wang, X.; Long, J. Layered $\mathrm{C}_{3} \mathrm{~N}_{3} \mathrm{~S}_{3}$ Polymer/Graphene Hybrids as Metal-Free Catalysts for Selective Photocatalytic Oxidation of Benzylic Alcohols under Visible Light. ACS Catal. 2014, 4, 3302-3306. [CrossRef]

23. Opembe, N.N.; Guild, C.; King'ondu, C.; Nelson, N.C.; Slowing, I.I.; Suib, S.L. Vapor-Phase Oxidation of Benzyl Alcohol Using Manganese Oxide Octahedral Molecular Sieves (OMS-2). Ind. Eng. Chem. Res. 2014, 53, 19044-19051. [CrossRef]

24. Sundar, J.V.; Subramanian, V. Novel Chemistry for the Selective Oxidation of Benzyl Alcohol by Graphene Oxide and N-Doped Graphene. Org. Lett. 2013, 15, 5920-5923. [CrossRef] [PubMed]

25. Liu, Y.; Zhang, P.; Tian, B.; Zhang, J. Core-Shell Structural CdS@SnO 2 Nanorods with Excellent Visible-Light Photocatalytic Activity for the Selective Oxidation of Benzyl Alcohol to Benzaldehyde. ACS Appl. Mater. Interfaces 2015, 7, 13849-13858. [CrossRef] [PubMed]

26. Huang, H.; Yuan, H.; Janssen, K.P.F.; Solís-Fernández, G.; Wang, Y.; Tan, C.Y.X.; Jonckheere, D.; Debroye, E.; Long, J.; Hendrix, J.; et al. Efficient and Selective Photocatalytic Oxidation of Benzylic Alcohols with Hybrid Organic-Inorganic Perovskite Materials. ACS Energy Lett. 2018, 3, 755-759. [CrossRef] 
27. Lahtinen, P.; Korpi, H.; Haavisto, E.; Leskela, M.; Repo, T. Parallel Screening of Homogeneous Copper Catalysts for the Oxidation of Benzylic Alcohols with Molecular Oxygen in Aqueous Solutions. J. Comb. Chem. 2004, 6, 967-973. [CrossRef] [PubMed]

28. Dun, R.; Wang, X.; Tan, M.; Huang, Z.; Huang, X.; Ding, W.; Lu, X. Quantitative Aerobic Oxidation of Primary Benzylic Alcohols to Aldehydes Catalyzed by Highly Efficient and Recyclable P123-Stabilized Pd Nanoclusters in Acidic Aqueous Solution. ACS Catal. 2013, 3, 3063-3066. [CrossRef]

29. Dhakshinamoorthy, A.; Alvaro, M.; Garcia, H. Aerobic Oxidation of Benzylic Alcohols Catalyzed by Metal-Organic Frameworks Assisted by TEMPO. ACS Catal. 2011, 1, 48-53. [CrossRef]

30. Chen, T.-R. Synthesis and characterization of cyclometalated iridium(III) complexes containing benzoxazole derivatives and different ancillary ligands. J. Organomet. Chem. 2008, 693, 3117-3130. [CrossRef]

31. Lee, H.-P.; Hsu, Y.-F.; Chen, T.-R.; Chen, J.-D.; Chen, K.H.-C.; Wang, J.-C. A Novel Cyclometalated Dimeric Iridium Complex, $\left[(\mathrm{dfpbo})_{2} \mathrm{Ir}_{2}\left[\mathrm{dfpbo}=2-\left(3,5-\right.\right.\right.$ Difluorophenyl)benzoxazolato- $\left.N, \mathrm{C}^{2^{\prime}}\right]$, Containing an Unsupported $\mathrm{Ir}^{\mathrm{II}}-\mathrm{Ir}^{\mathrm{II}}$ Bond. Inorg. Chem. 2009, 48, 1263-1265. [CrossRef] [PubMed]

32. Chen, T.-R.; Lee, H.-P.; Chen, J.-D. Water Attack Umpolung Aromatic Systems to Release Hydrogen. Inorg. Chem. 2011, 50, 3645-3650. [CrossRef] [PubMed]

33. Hoff, C.D. Thermodynamic and kinetic studies of stable low valent transition metal radical complexes. Coord. Chem. Rev. 2000, 206, 451-467. [CrossRef]

34. Lehman, M.C.; Pahls, D.R.; Meredith, J.M.; Sommer, R.D.; Heinekey, D.M.; Cundari, T.R.; Ison, E.A. Oxyfunctionalization with CpIr III $(\mathrm{NHC})(\mathrm{Me})(\mathrm{Cl})$ with $\mathrm{O}_{2}$ : Identification of a Rare Bimetallic $\operatorname{Ir}^{\mathrm{IV}} \mu-\mathrm{Oxo}$ Intermediate. J. Am. Chem. Soc. 2015, 137, 3574-3584. [CrossRef] [PubMed]

35. Rendina, L.M.; Puddephatt, R.J. Oxidative Addition Reactions of Organoplatinum(II) Complexes with Nitrogen-Donor Ligands. Chem. Rev. 1997, 97, 1735-1754. [CrossRef] [PubMed]

36. Medvedev, A.G.; Mikhaylov, A.A.; Churakov, A.V.; Vener, M.V.; Tripol'skaya, T.A.; Cohen, S.; Lev, O.; Prikhodchenko, P.V. Potassium, Cesium, and Ammonium Peroxogermanates with Inorganic Hexanuclear Peroxo Bridged Germanium Anion Isolated from Aqueous Solution. Inorg. Chem. 2015, 54, 8058-8065. [CrossRef] [PubMed]

37. Li, X.-H.; Wang, X.; Antonietti, M. Solvent-Free and Metal-Free Oxidation of Toluene Using $\mathrm{O}_{2}$ and g- $\mathrm{C}_{3} \mathrm{~N}_{4}$ with Nanopores: Nanostructure Boosts the Catalytic Selectivity. ACS Catal. 2012, 2, 2082-2086. [CrossRef]

38. Gunduz, G.; Akpolat, O. Catalytic vapor-phase oxidation of toluene to benzaldehyde. Ind. Eng. Chem. Res. 1990, 29, 45-48. [CrossRef]

39. Mao, Y.; Bakac, A. Photocatalytic Oxidation of Toluene to Benzaldehyde by Molecular Oxygen. J. Phys. Chem. 1996, 100, 4219-4223. [CrossRef]

40. Borgaonkar, H.V.; Raverkar, S.R.; Chandalia, S.B. Liquid phase oxidation of toluene to benzaldehyde by air. Ind. Eng. Chem. Prod. Res. Dev. 1984, 23, 455-458. [CrossRef]

41. Eyal, G.; Ibrahim, A. Cerium-Catalyzed Selective Oxidation of Alkylbenzenes with Bromate Salts. Synth. Commun. 1995, 25, 3149-3154.

42. Pierre, P.M. Process of Making Aromatic Aldehyde. US Patent 613460A, 1 November 1898.

43. Bazlen, M. Process of Making Aromatic Aldehyde and Acid. US Patent 698355, 22 April 1902.

44. Bazlen, M.; Labhardt, H. Process of Oxidizing Methyl Groups in Aromatic Hydrocarbons. US Patent 780404, 17 January 1905.

(C) 2018 by the authors. Licensee MDPI, Basel, Switzerland. This article is an open access article distributed under the terms and conditions of the Creative Commons Attribution (CC BY) license (http://creativecommons.org/licenses/by/4.0/). 